VÁCLAV BLAŽEK

Department of Linguistics and Baltic Studies

Masaryk University - Brno

ORCID: 0000-0002-6797-7188

e-mail: blazek@phil.muni.cz

\title{
CLASSIFICATION OF SLAVIC LANGUAGES: EVOLUTION OF DEVELOPMENTAL MODELS
}

An awareness of a common origin of the Slavs was preserved in the social memory at least till the beginning of the 12th century, when the chronicler Nestor recorded it.

Во мнозъхъ же времннъ ${ }^{x}$. стьли суть Словтни по Дунаєви . гдъ єсть нъине Оугорьска земля

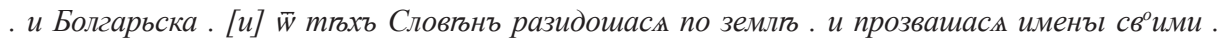

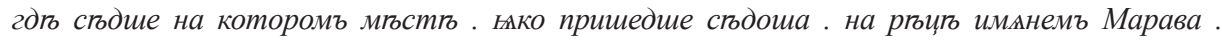
и прозвашасл Морава . а друзии Чеси нарекошас . а се ти же Словъни Хровате Бтлии . и Серебъ . и Хорутане. Волхомь бо намедмемь на Словъни на Дунаискисе . [и] стодемь в ни

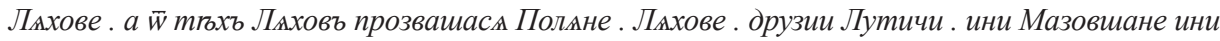
Поморяне . такоже и ти Словъне пришедше и съдоша по Днгпру . и наре-кошася Полмне . а друзии Древльне зане сгдоша в льсьь ${ }^{x}$. а друзии спдоша межю Припетью и Двиною. и нарекошасп Дреговичи . [инии съдоша на Двинг и нарекоша ${ }^{\wedge}$ Полочане] рьчьки ради няже втечеть въ Двину . имлнемь Полота . $\bar{w}$ сен прозвашася Полочане. Словтни же спдоша жколо єзера Илмеря. [и] прозвашася свомь имлнемь и сдълама градъ . и нарекома и Новъгородъ . а друзии сгодоша по Деснг . и по Съли по Суль и нарекоша Съверъ . [и] тако разидеся Словъньскии низълкъ тьмже и грамота прозвася Словьньскан.

Повгсть времлньныхъ льтьъ „Tale of Bygone Years” or 'Primary Chronicle' (Laurentian redaction, 1377: 5.23-6.24) http://litopys.org.ua/lavrlet/lavr01.htmhttp://hudce7.harvard.edu/ ostro-wski/pvl/volla.pdf

Over a long period the Slavs settled beside the Danube, where the Hungarian and Bulgarian lands now lie. From among these Slavs, parties scattered throughout the country and were known by appropriate names, according to the places where they settled. Thus some came and settled by the river Morava, and were named Moravians, while others were called Czechs. Among these same Slavs are included the White Croats, the Serbs, and the Carinthians. For when the Vlakhs attacked the Danubian Slavs, settled among them, and did them violence, the latter came and made their homes by the Vistula, and were then called Lyakhs. Of these same 
Lyakhs some were called Polyanians, some Lutichians, some Mazovians, and still others Pomorians. Certain Slavs settled also on the Dnieper, and were likewise called Polyanians. Still others were named Derevlians, because they lived in the forests. Some also lived between the Pripet' and the Dvina, and were known as Dregovichians. Other tribes resided along the Dvina and were called Polotians on account of a small stream called the Polota, which flows into the Dvina. It was from this same stream that they were named Polotians. The Slavs also dwelt about Lake Il'men', and were known there by their characteristic name. They built a city which they called Novgorod. Still others had their homes along the Desna, the Sem', and the Sula, and were called Severians. Thus the Slavic race was divided, and its language was known as Slavic."

Translated and edited by Samuel Hazzard Cross \& Olgerd p. Sherbowitz-Wetzorhttps:// ia800608.us.archive.org/10/items/TheRussianPrimaryChronicle/the\%20russian\%20primary\%20chronicle.pdf

\section{Qualitative models}

In the 17th cent. the Croatian Jesuit Juraj Križanić (1666) offered the first classification of the Slavic languages, recognizing the languages Russians, Lekhians = Poles, Czechs, besides Trans-Danubian: Bulgarians, Serbians and Croats. Already in the following century practically all Slavic languages are differentiated, but instead of schemes of classification they are arranged into specific lists. With regard to variable terminology it is useful to present some examples with modern counterparts.

\section{Classification based on enumeration}

1.1. Schlözer (1771, 331-34; see Dobrovský 1792, 17): 1) Russisch = Russian; 2) Polnisch = Polish; 3) Böhmisch = Czech; 4) Lausitzisch = Lusatian (Sorbian); 5) Polabisch = Polabian; 6) Windisch = Slovenian; 7) Kroatisch = Croatian; 8) Bosnisch = Bosnian (Serbian?); 9) Bulgarisch = Bulgarian.

1.2. Rüdiger (1782, 62; see Dobrovský 1792, 17-18): 1) Altslavonisch = Old Church Slavonic; 2) Russisch = Russian; 3) Polnisch = Polish; 4) Wendisch in der Oberlausitz = Upper Sorbian; 5) Wendisch in der Niederlausitz = Lower Sorbian; 6) eine ähnliche Mundart im Lüneburgischen = Polabian; 7) Böhmisch = Czech; 8) Windisch in Kärnten und Krain = Slovenian; 9) Illyrisch in Kroatien, Slawonien, Dalmatien = Croatian; 10) Serbisch (welches sich mit über Bulgarien ersteckt) = Serbian.

1.3. Pallas (1786-89, 1 etc.; see Jagić 1898, 13): 1) Kirchenslavisch = Old Church Slavonic; 2) Slavoungarisch $=$ Slovak; 3) Illyrisch $=$ Croatian; 4) Böhmisch $=$ Czech; 5) Serbisch (der ungarische Serben) = Serbian; 6) Wendisch = Upper Sorbian; 7) Sorabisch = Lower Sorbian; 8) Polabisch = Polabian; 9) Kaschubisch = Kašubian; 10) Polnisch = Polish; 11) Kleinrussisch = Ukrainian; 12) Suzdalisch = Russian.

1.4. Gebhardi (1789, 235; see Dobrovský 1792, 18): 1) Slawisch (die Sprache der von Cyrillus herrühenden Kirchenschriften) = Old Church Slavonic; 2) Böhmisch 
oder Tschechisch $=$ Czech; 3) Bulgarisch $=$ Bulgarian; 4) Illyrisch = Croatian; 5) Serbisch $=$ Serbian; 6) Sorabisch in der Lausitz $=$ Upper Sorbian; 7) Wendisch $=$ Lower Sorbian; 8) Polnisch = Polish; 9) Ukrainisch oder die Sprache der Kosaken $=$ Ukrainian; 10. Susdalisch $=$ Suzdalian; 11) Russisch $=$ Russian.

1.5. Dobrovský $(1792,22)$ himself defined only five main Slavic dialects with explanation that their speakers formed their own states: 1) Russisch = Russian; 2) Polnisch = Polish; 3) Illyrisch (nach verschiedenen Mundarten, als der bulgarischen, raitzisch-serbischen, slawonischen, bosnischen, dalmatischen, ragusinischen) $=$ Bulgarian, Rača-Serbian, Slavonia-Serbian, Bosnian, while Dalmatian and Ragusine, originally Romance dialects, were assimilated by Croatian; 4) Kroatisch (mit dem Windischen in Steiermark, Krain und Kärnten) $=$ Croatian with Slovenian; 5) Böhmisch (mit dem Mährischen, Schlesischen um Troppau und Slowakischen in Ober-Ungarn $)=$ Czech with Moravian and Silesian dialects around Opava, plus Slovak in Upper Hungary. Concerning Lusatian, he wrote: 'Das Wendifche, in beiden Laufitzen ist ein aus Polnifchen und Böhmifchen gemifchte Mundart.' Later $(1796,127)$ he

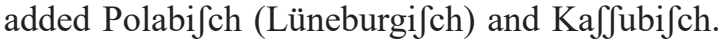

But already in the first decade of the 19th century a serious approach operating with specific isoglosses was developed. In the following two centuries an abundant array of models of internal classification of the Slavic languages was presented, usually based on phonologic, less frequently morphologic isoglosses. Let us summarize the most important models, arranged according to their segmentation into two or as many as seven daughter branches.

\section{Dichotomic classifications}

\subsection{West vs. Southeast}

Contrary to his classification from 1792, which reflected more historical-political than linguistic facts, Dobrovský's later models (1796, 126-27; 1809, v; 1818, 30-33; 1819 , iv-v) operated with historical phonetics of the Slavic languages. Isoglosses, as illustrated by his concrete examples, are still recognized today.

Diagram 1

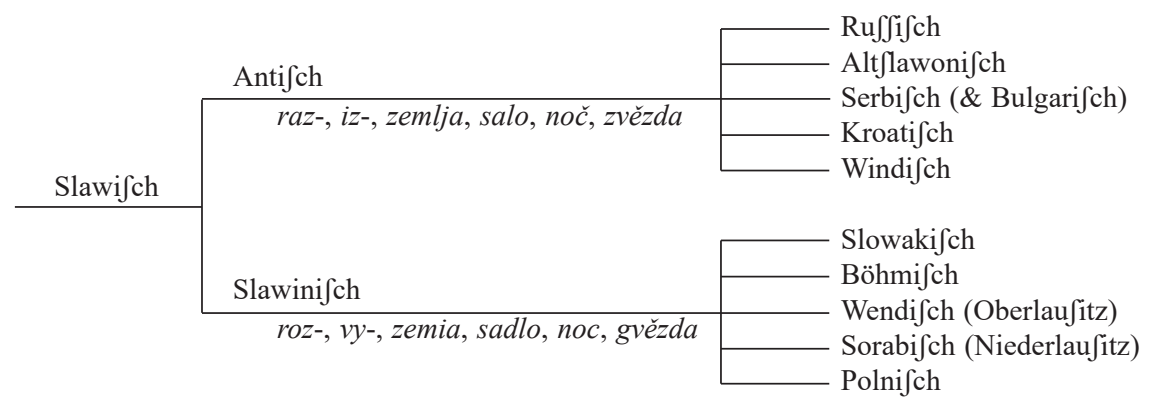


Šafařík $(1837,483)$ presented a more structured scheme:

Diagram 2

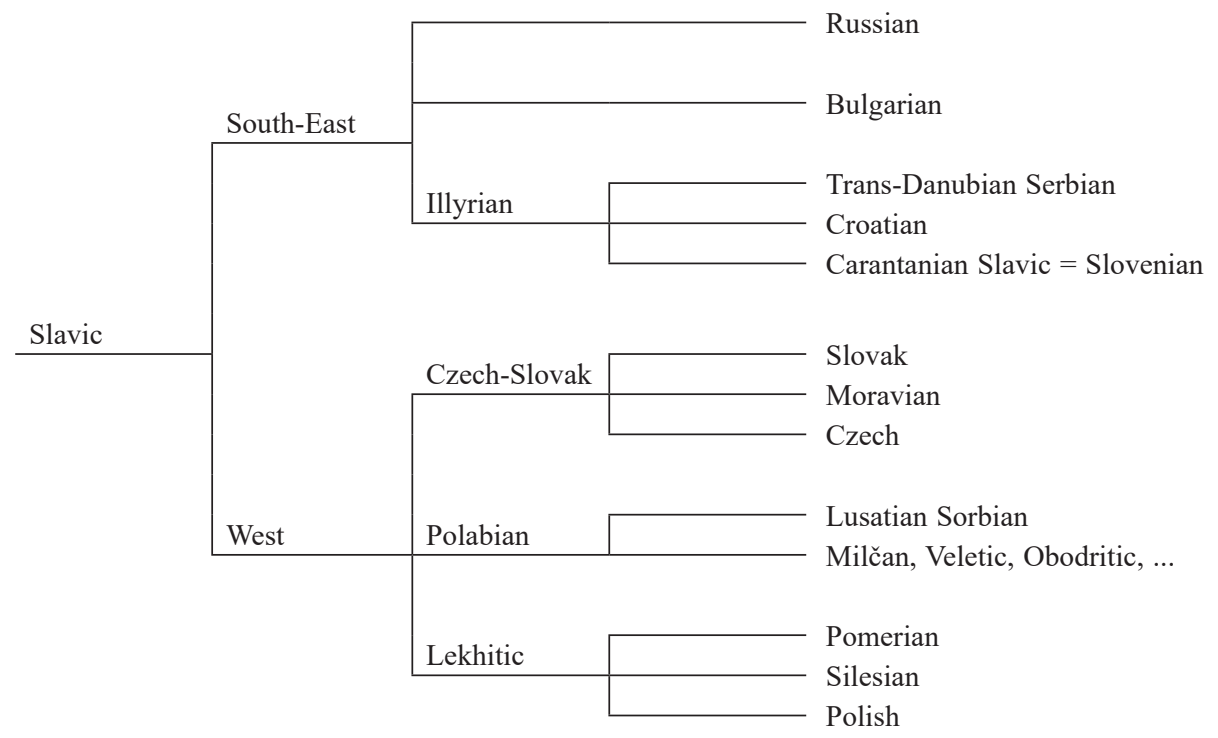

A similar model with a more detailed segmentation in daughter branches was proposed by Schleicher (1850, 201-19), but yet not in the form of his famous Stammbaum diagram:

Diagram 3

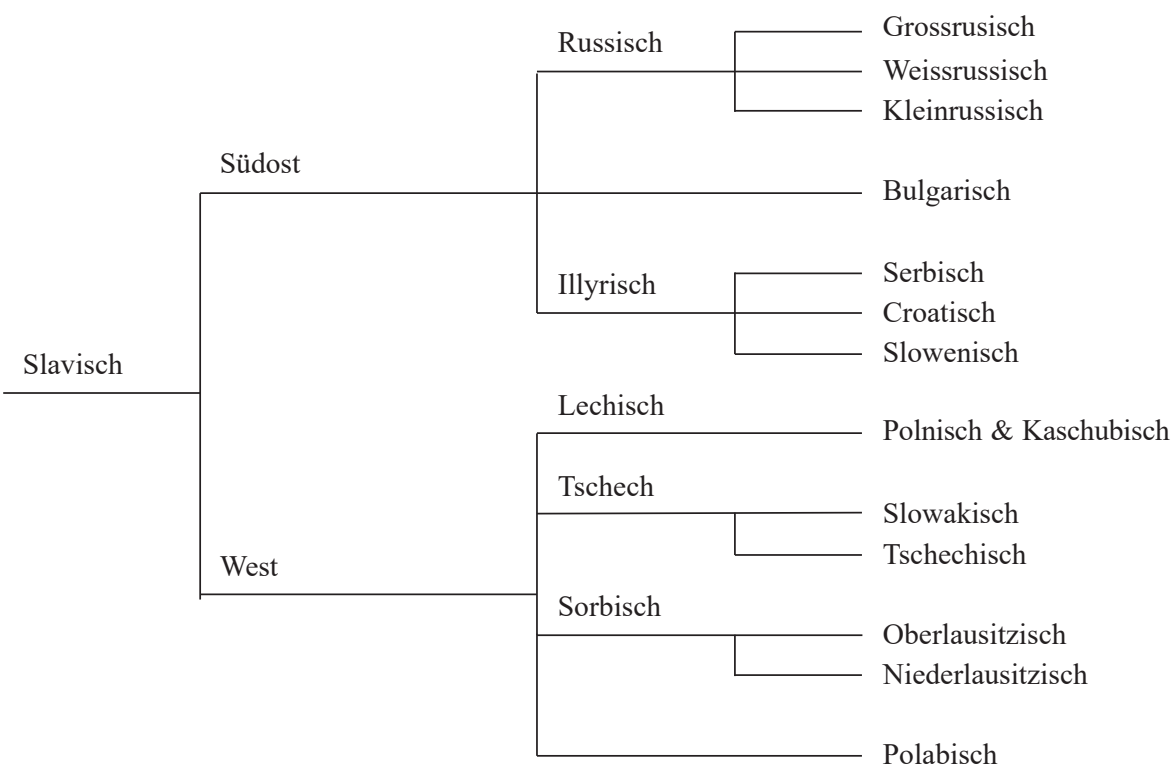


A practically identical model, but for the first time realized as a tree-diagram, belongs to František Ladislav Čelakovský (1799-1852), published posthumously in 1853. Lemeškin $(2008,127)$ mentions that Čelakovský probably used this diagram even earlier in his courses on Slavic linguistics. In any case, he is the first known author applying this transparent form to depict the mutual relations between languages. Schleicher adopted it during his seven-year-stay in Prague and successfully spread it so widely that the tree-diagram is used till the present time.

Čelakovský 1853, 3 :

Diagram 4

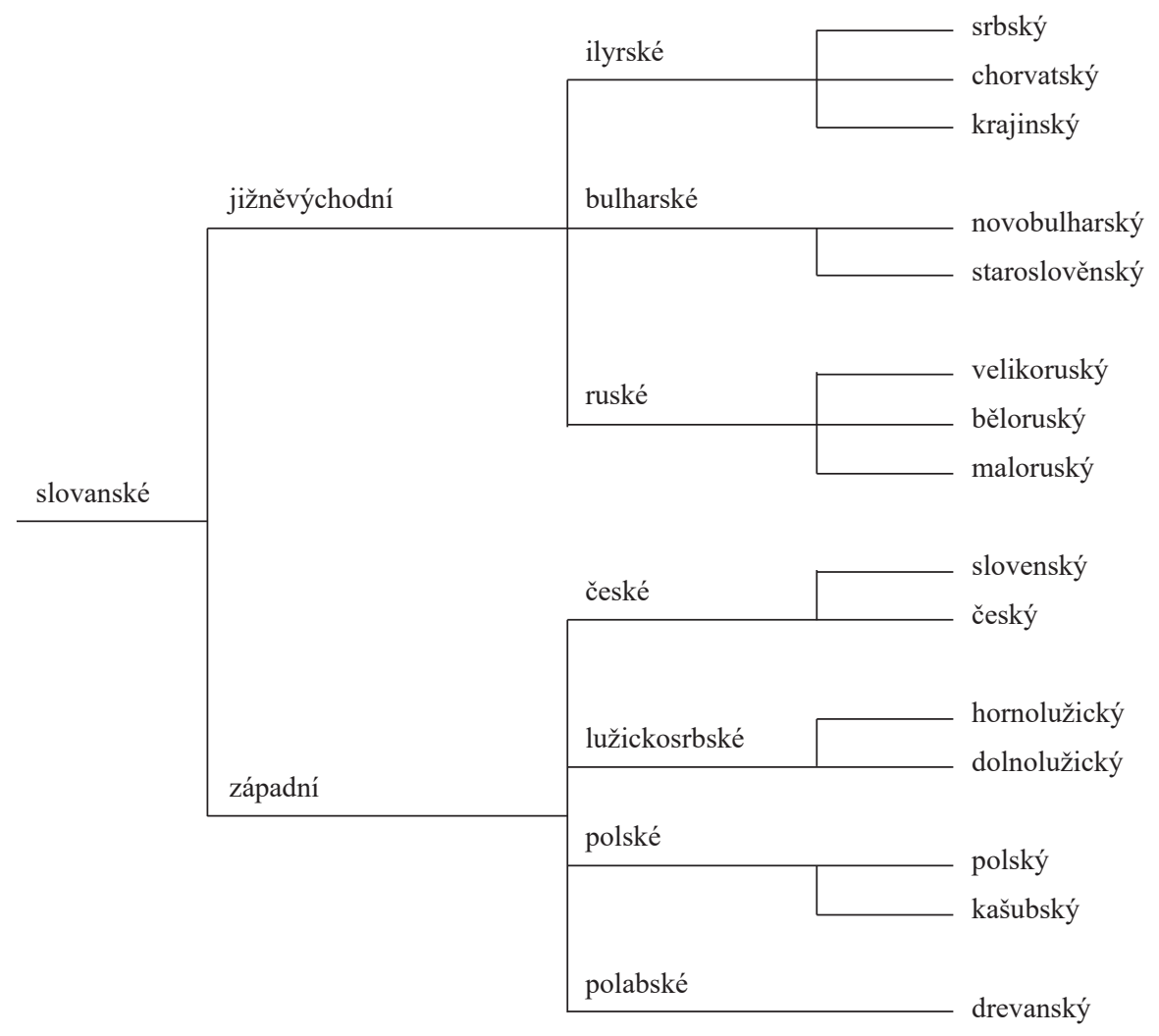

Later Schleicher $(1865,61)$ presented his own tree-diagram, which is more hierarchic than his model from 1850 : 


\section{Diagram 5}

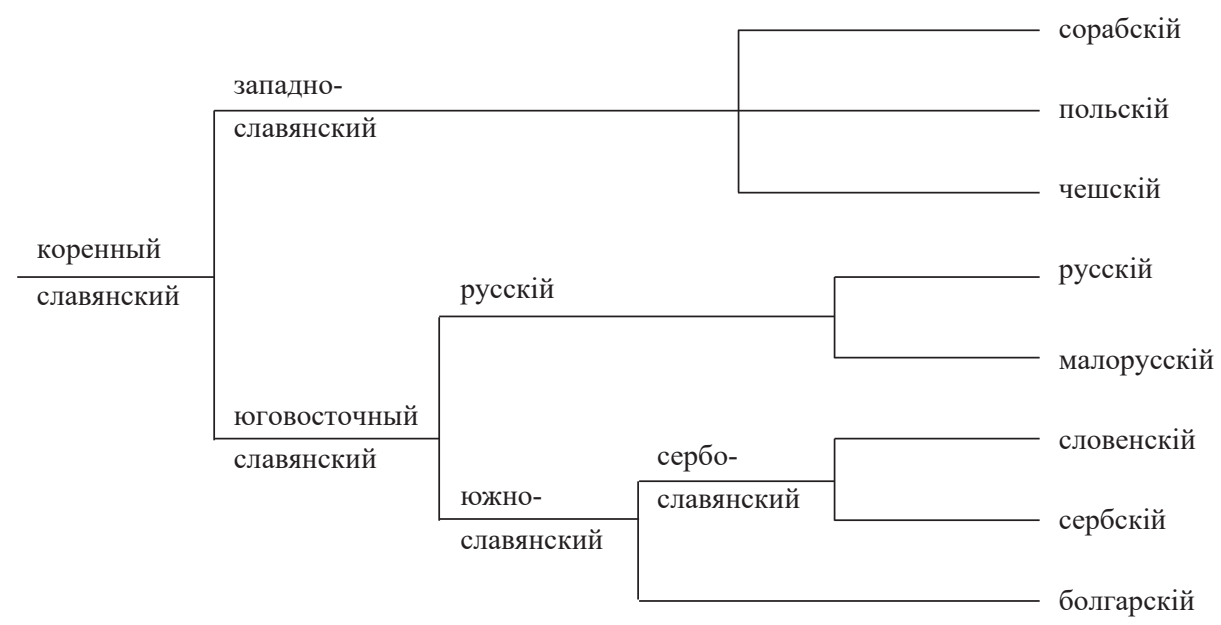

A similar model, proposed by Holub \& Kopečný (1952, 13-14) and Bernštejn (1961, 69-70), is depicted as Diagram 6:

Diagram 6

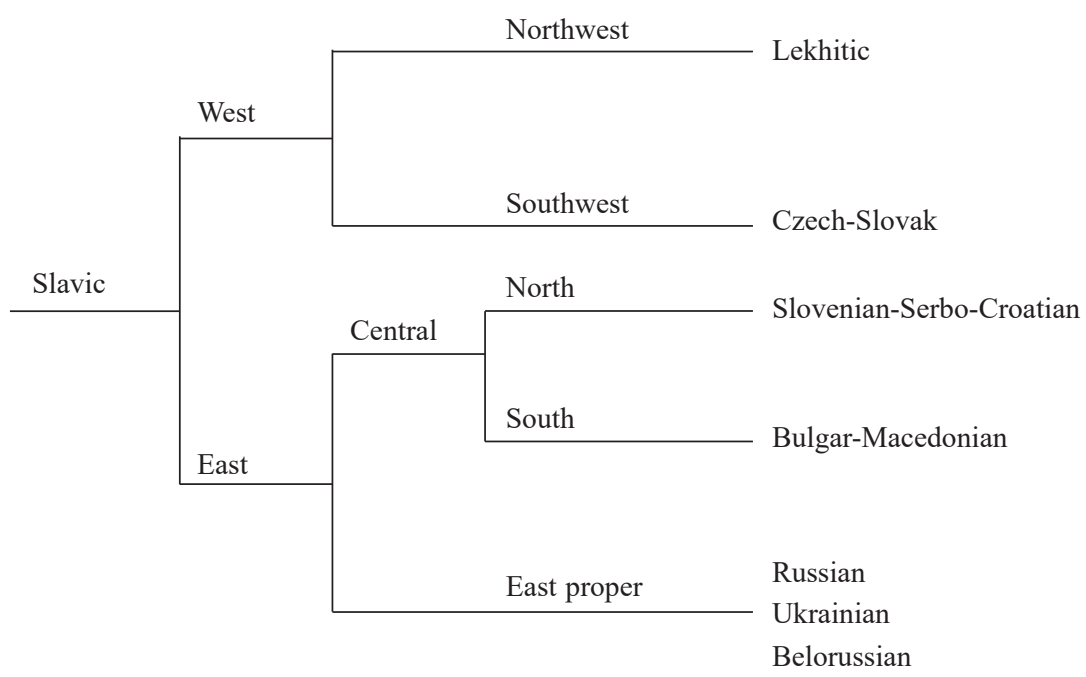

\subsection{North vs. South}

It was probably already Križanić (1666), who thought about the North-South dichotomy. His idea was developed by Kopitar (1836, XLVIII), who introduced the Danube as the dividing line: 


\section{Diagram 7}

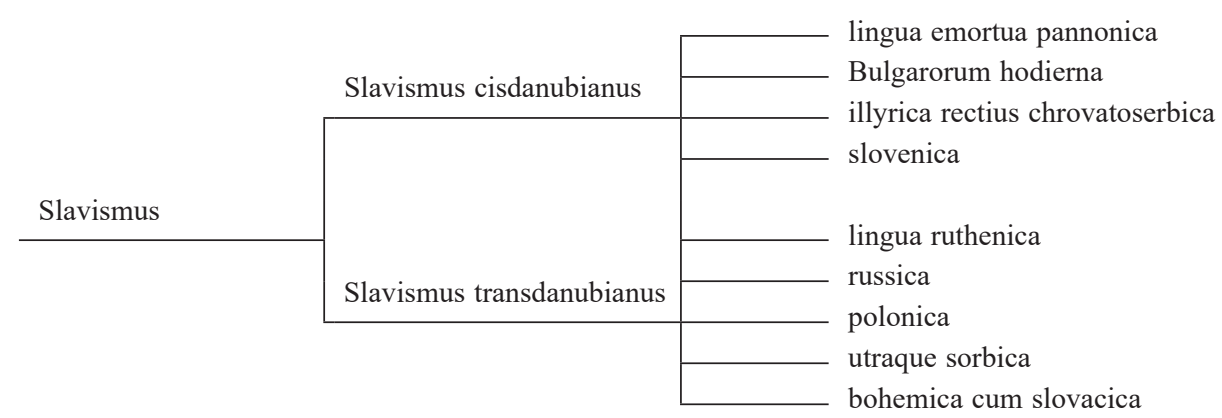

Mareš $(1956,1969)$ gave reasons for it in terms of historical phonetics.

\section{Diagram 8}

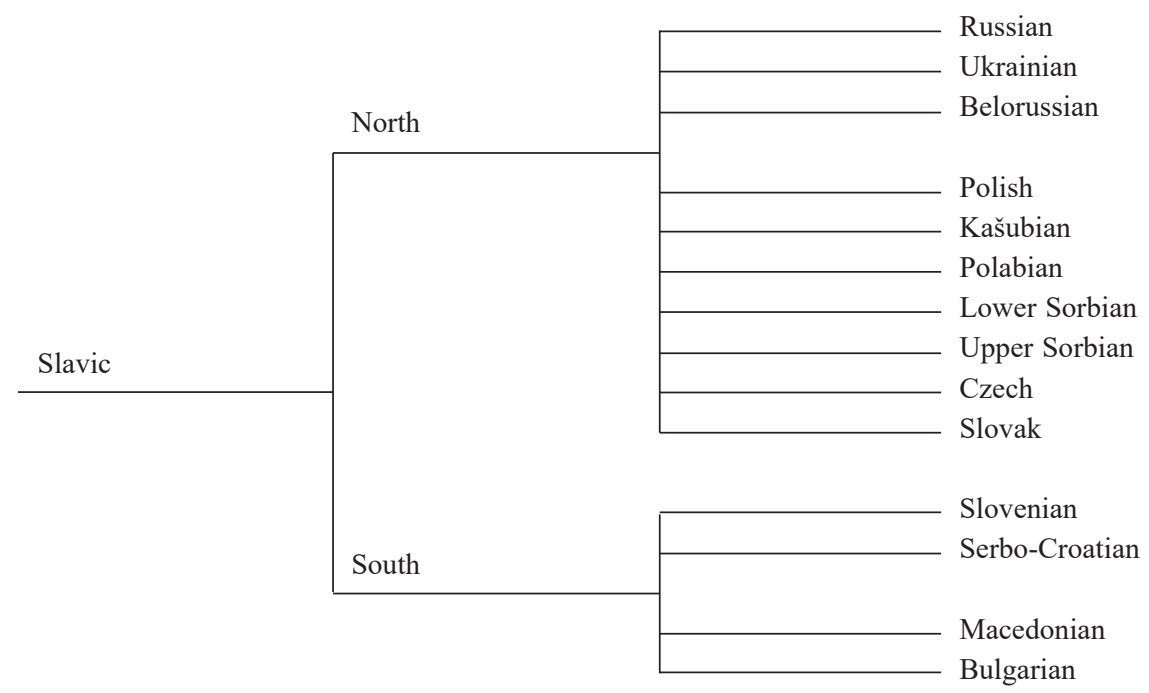

Note: Later Mareš (1980) changed his model in favor of tetrachotomic classification.

A specific variant of dichotomic classification was formulated by Zaliznjak (1988, 176). He defined two primary branches, Northwest and Southeast. Thanks to their interference a belt of transitional tribal dialects had to originate. Schematically:

\section{Diagram 9}

\begin{tabular}{l|ll}
\multicolumn{1}{c}{} & Northwest & $\begin{array}{l}\text { North Krivičian, Kašubian \& Pomerian Slovincian, Polish } \\
\text { Upper \& Lower Sorbian }\end{array}$ \\
\cline { 2 - 3 } Slavic & transitional & Old Novgorodian, South Krivičian, Rostov-Suzdalian, \\
& Slovak, Czech & \\
& Southeast & Slovenian, Serbo-Croatian, Bulgarian \\
\cline { 2 - 3 } & south dialects of East Slavic continuum, Ilmeň-Slověnian
\end{tabular}


Zaliznjak's pupil Nikolajev $(1994,35)$ defined the Antian and Slověnian components according to shift of accent:

\section{Diagram 10}

\begin{tabular}{|c|c|c|}
\hline \multirow[b]{2}{*}{ Slavic } & Antian & Krivičian, Radimičian, Ukrainian dialects of Galicia \& Podolje, Upper Sorbian, \\
\hline & \multirow[b]{2}{*}{ lověnian } & Čakavish (Suska-Sali), East Štokavish, West Bulgarian \\
\hline & & Ilmeň-Slověnian, South Great Russian, South Belorussian, North \& East Ukrainian \\
\hline
\end{tabular}

Note: The Slavic languages for which the relevant accentologic data are missing, are not included in Nikolaev's model.

\section{Trichotomic classification}

Probably the first to introduce the following tripartite division of the Slavic languages was Vostokov (1820), followed e.g. by Jagić (1910) and most of the Czech Slavists (e.g. Horálek 1955, 55-59). This traditional model may be illustrated by Diagram 11 used by Ivanov $(1990,95)$ :

\section{Diagram 11}

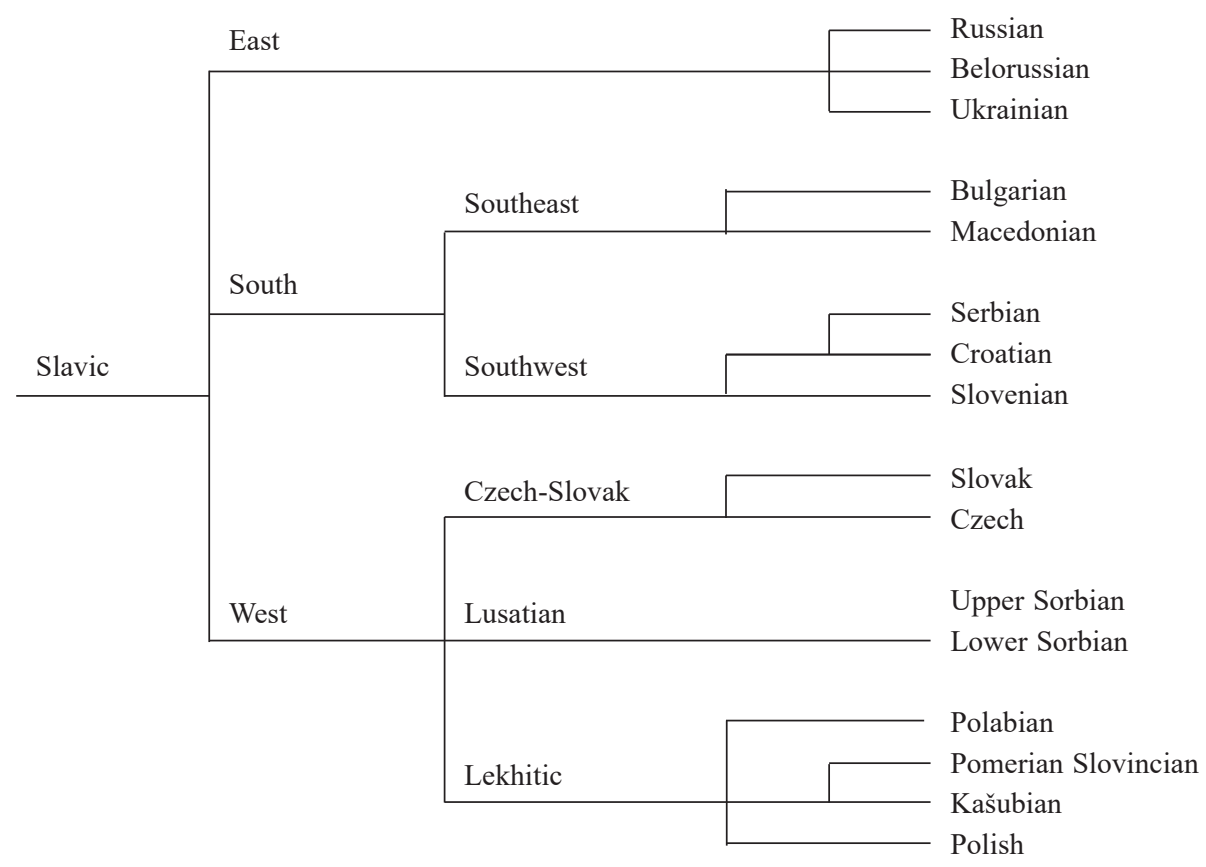




\section{Tetrachotomic classification}

Leskien (1876) separated the Bulgar-Macedonian and Serbo-Croatian - Slovenian branches:

\section{Diagram 12}

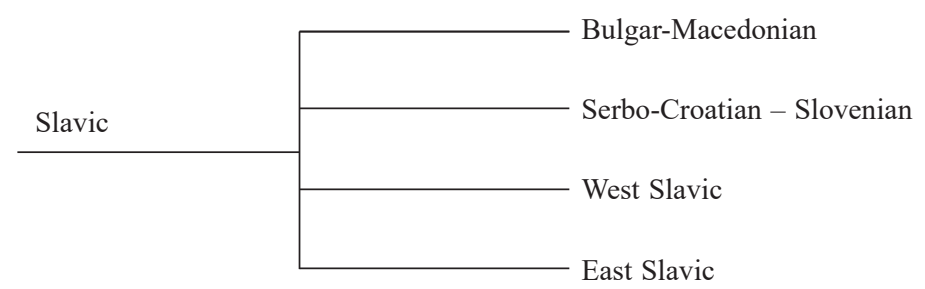

Mareš (1980) modified his older model into two dichotomic stages, representing a final tetrachotomy:

\section{Diagram 13}

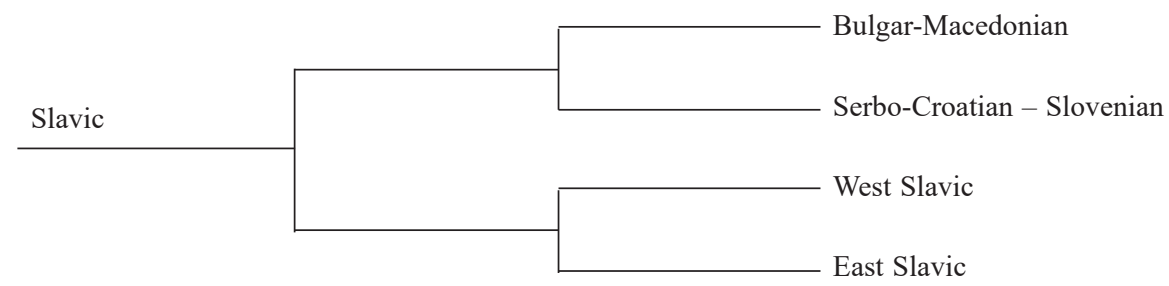

This model of two dichotomies was already preceded by the scheme of Kucharski $(1836,851)$, who joined East Slavic with Old Church Slavonic \& Bulgarian:

\section{Diagram 14}

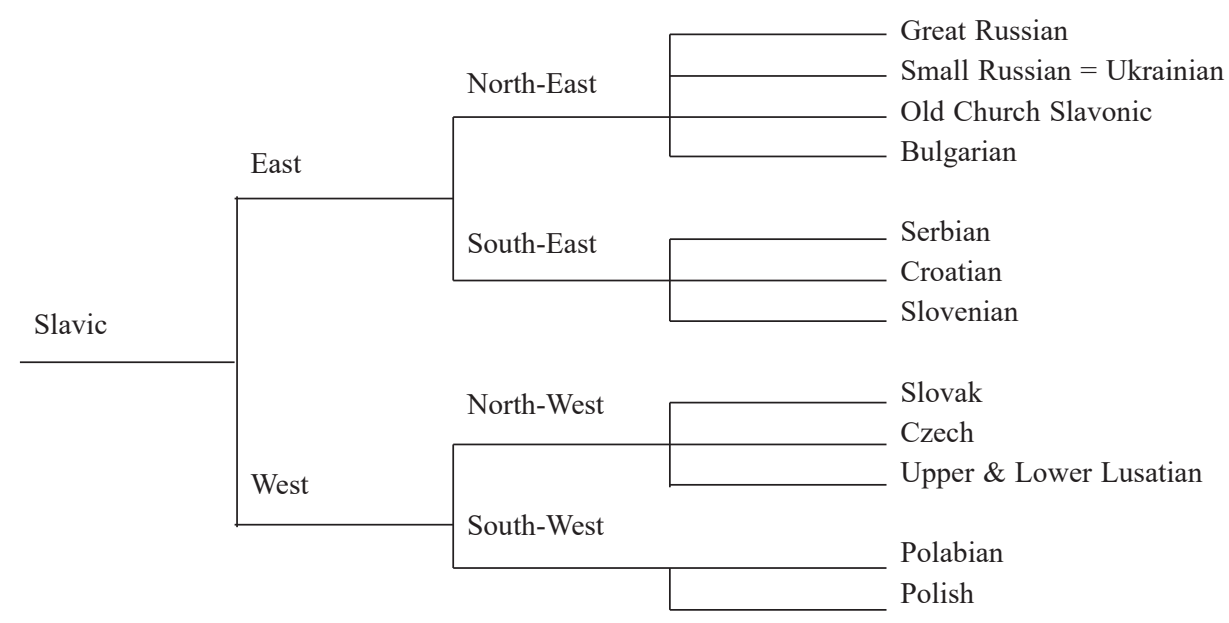




\section{Pentachotomic classification}

Kopečný (1949) presented his pentachotomic model, but surprisingly without the Lusatian branch:

\section{Diagram 15}

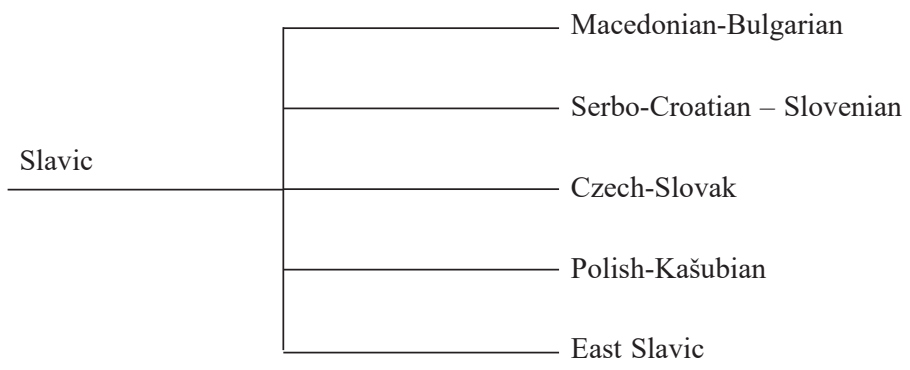

\section{Hexachotomic classification}

In his classification from 1953 Jakubinskij divided the Slavic languages into six equivalent branches, now including the Lusatian branch:

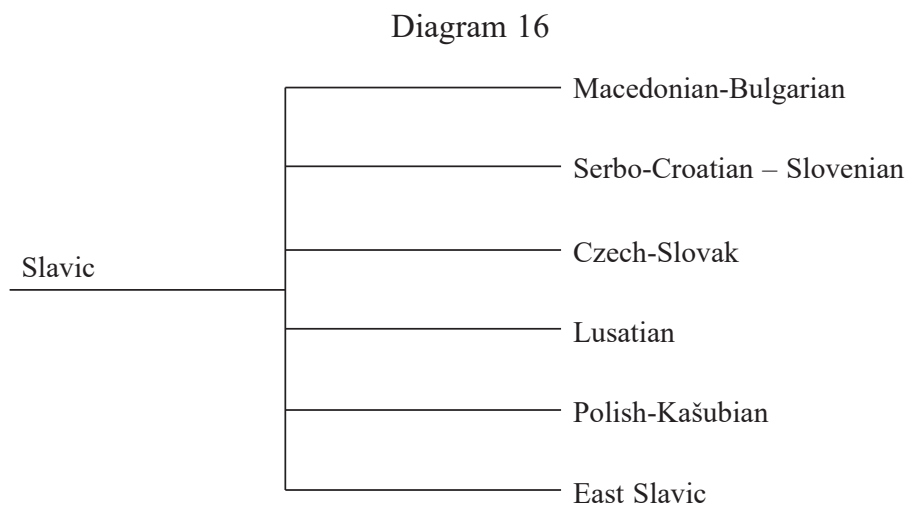

\section{Heptachotomic classification}

Besides the tree-diagram Ivanov $(1990,96)$ applied the net-scheme. Contrary to his predecessors he introduced as an individual branch the language of inscriptions on birch bark from Novgorod and placed it in the northeast periphery. 


\section{Diagram 17}

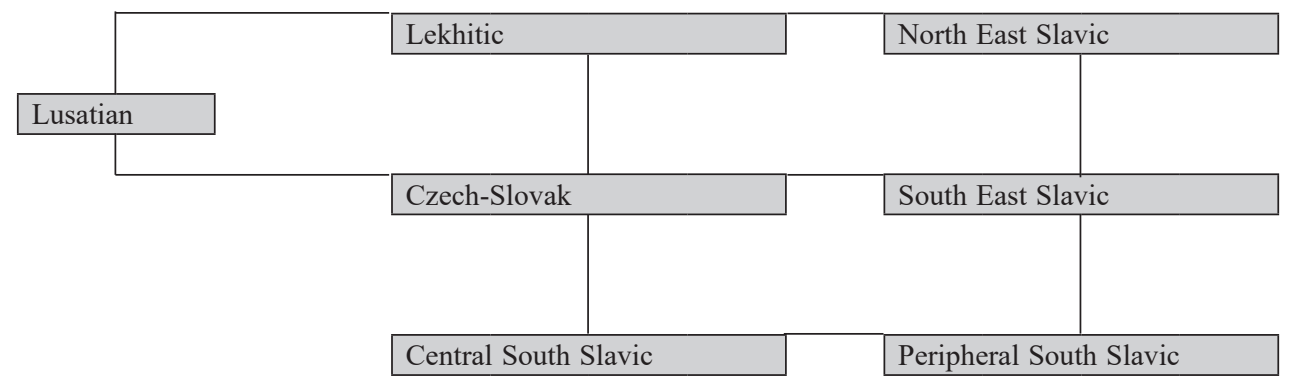

Such a model of language classification is only complete, if takes in account all descendant languages, including transitional and peripheral tribal dialects, known only from borrowings or proper names. In the case of the Slavic dialect continuum, the following idioms are assumed:

The language of the Pannonian Slavs, reconstructed on the basis of lexical and onomastic borrowings in Hungarian, standing close to Serbo-Croatian (Chelimskij 1988), with overlap in Central Slovak and probably also partially in Southwest Czech.

The language of the Slavs, which penetrated into the territory of Greece, reconstructed on the basis of Byzantine sources; closest are Old Church Slavonic, now modern Macedonian and Bulgarian, but in the earliest layer the sequences talt, tart, telt, tert are still preserved (Vasmer 1941).

The language leaving the earliest Slavic contribution in Romanian and Albanian, including toponymy, which is not always characterized by South Slavic features (Trubačev 2000).

The language of the Slavic settlement along the Upper Danube, i.e. in Upper Austria and Bavaria, reconstructible only with help of toponymy (Schwarz 1960; Šmilauer 1963).

The language of the Slavic settlement from the basin of the Saal, standing close to Upper Sorbian, also preserved only in toponymy.

In the Slavic northwest periphery there were two fragmentarily documented languages, Polabian and Pomerian. In the northeast periphery the tribal dialect of Krivičians left non-literary texts on birch bark from medieval Novgorod and Pskov. They are characterized by specific phonologic, morphologic and syntactic archaisms, besides some lexical isoglosses, separating them from their dominant neighbors, in the former case Lekhitic, in the latter case East Slavic. Inconsistent results in the lexicostatistic analysis of both Žuravlev and our application of glottochronology indicate that they may have represented the frontiers of the earliest Slavic migrational waves, which had already separated before disintegration of the main Slavic dialect continuum. The oldest layer of the Slavic loanwords in Albanian and Romanian may reflect the first migrational wave headed to the south.

The net diagram is especially useful, if we study mutual relations with fragmentarily described languages, known only from limited epigraphic material or even only thanks to borrowings and onomastics. It allows us to depict multi-level rela- 
tions, naturally only in the qualitatative perspective. Applying it to the Slavic languages, it is possible to add to the net-model some 'relic' dialects which were never recorded:

Diagram 18

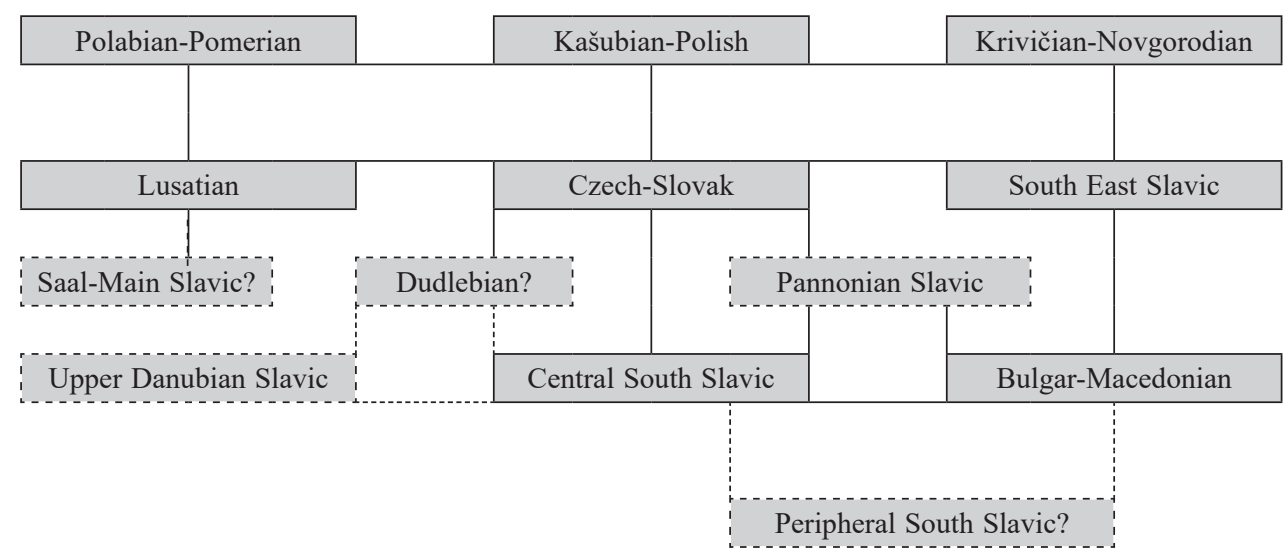

\section{Quantitative methods}

\section{Quantitative methods}

Žuravlev (1994) applied a lexicostatistic test operating with a big lexical corpus of all Slavic languages, summarized in volumes 1-15 of ,Etymological Dictionary of the Slavic Languages", edited by Oleg N. Trubačev (Moskva 1974f). To express the mutual relationship between individual Slavic languages, he used a formula which preferred the exclusivity of cognates (p. 64):

$$
\mathrm{G}(\mathrm{A}, \mathrm{B})=\underset{2}{\Sigma} \underset{2}{\mathrm{n}}\left[(\mathrm{n}+2-\mathrm{i}) \times \mathrm{V}(\mathrm{A}, \mathrm{B})_{\mathrm{i}}\right] / \mathrm{H}(\mathrm{A}) \times \mathrm{H}(\mathrm{B}),
$$

where A, B are two related languages, whose closeness is tested; $\mathrm{H}(\mathrm{A})$ means the lexicon of the language $A$ inherited from the Slavic protolanguage; $n$ is the number of languages used for calculation; i represents the number of languages sharing a given isogloss. The highest weight belongs to any isogloss attested in only two languages $(i=2)$, and the lowest weight belongs to any isogloss which is attested in all of the languages considered $(i=n)$. Thus the numerically highest result expresses the closest relationship, which, according to Žuravlev, is 1.935 for the pair of Upper and Lower Sorbian. 
Table 1a

\begin{tabular}{|c|c|c|c|c|c|c|c|c|c|c|c|c|c|}
\hline & Mac. & SC. & Sln. & Slk. & Cz. & USo. & LSo. & Plb. & Kaš. & Pol. & Br. & Ukr. & Rus. \\
\hline Bul. & 1.727 & 1.267 & 1.202 & 0.980 & 0.995 & 0.897 & 0.823 & 0.735 & 0.846 & 0.931 & 0.894 & 0.967 & 0.945 \\
\hline Mac. & & 1.262 & 1.243 & 0.988 & 0.932 & 0.911 & 0.864 & 0.879 & 0.885 & 0.865 & 0.834 & 0.910 & 0.870 \\
\hline SC. & & & 1.296 & 0.977 & 1.036 & 0.879 & 0.809 & 0.664 & 0.861 & 0.955 & 0.890 & 0.960 & 0.989 \\
\hline Sln. & & & 1.058 & 1.077 & 1.006 & 0.933 & 0.808 & 0.887 & 0.955 & 0.895 & 0.987 & 0.943 \\
\hline Slk. & & & & & 1.362 & 1.185 & 1.169 & 0.828 & 1.149 & 1.199 & 1.029 & 1.084 & 0.915 \\
\hline Cz. & & & & & 1.100 & 1.029 & 0.738 & 0.993 & 1.163 & 0.960 & 1.027 & 0.945 \\
\hline USo. & & & & & & & 1.935 & 1.155 & 1.274 & 1.123 & 0.940 & 0.946 & 0.816 \\
\hline LSo. & & & & & & & 1.348 & 1.383 & 1.138 & 0.915 & 0.909 & 0.785 \\
\hline Plb. & & & & & & & & 1.296 & 0.897 & 0.690 & 0.691 & 0.635 \\
\hline Kaš. & & & & & & & & & & 1.382 & 0.991 & 0.955 & 0.841 \\
\hline Pol. & & & & & & & & & & & 1.114 & 1.122 & 0.994 \\
\hline Br. & & & & & & & & & & & & 1.375 & 1.270 \\
\hline Ukr. & & & & & & & & & & & & & 1.201 \\
\hline \hline
\end{tabular}

Žuravlev's results may be also applied to inter-group comparison:

Table $1 b$

\begin{tabular}{|l|c|c|c|c|c|c|}
\hline & SC.-Sln. & Cz.-Slk. & Lus. & Plb. & Kaš.-Pol. & ES1. \\
\hline Bul.-Mac. & 1.243 & 0.974 & 0.874 & 0.807 & 0.882 & 0.903 \\
\hline SC.-Sln. & & 1.037 & 0.907 & 0.736 & 0.915 & 0.944 \\
\hline Cz.-Slk. & & & 1.121 & 0.783 & 1.126 & 0.993 \\
\hline Lus. & & & & 1.252 & 1.230 & 0.885 \\
\hline Plb. & & & & & 1.097 & 0.672 \\
\hline Kaš.-Pol. & & & & & & 1.003 \\
\hline
\end{tabular}

From here it is possible to define three branches:

South Slavic 1.243, East Slavic 1.236, West Slavic 1.120 (1.160 without Polabian):

Table 1c

\begin{tabular}{|r||c|c|c|c|c|}
\hline & WSl. including Plb. & ESl. & & WSl. without Plb. & ESl. \\
\hline SSl. & 0.906 & 0.924 & SSl. & 0.929 & 0.924 \\
\hline WS1. & & 0.919 & WSl. & & 0.960 \\
\hline
\end{tabular}

If Polabian is included, the closest relation appears between the South and East Slavic branches, weakest would be the link between West and South Slavic. But the differences are very small, they are in the interval of $2 \%$. On the other hand, if Polabian is excluded, the closest are West and East Slavic and weakest are South and East 
Slavic relations. These seemingly paradoxical results may be interpreted as variances from some balance value (ø 0.916), reflecting the tripartite division into three more or less equidistant branches. Žuravlev did not try to depict his results by any diagram, it is our responsibility:

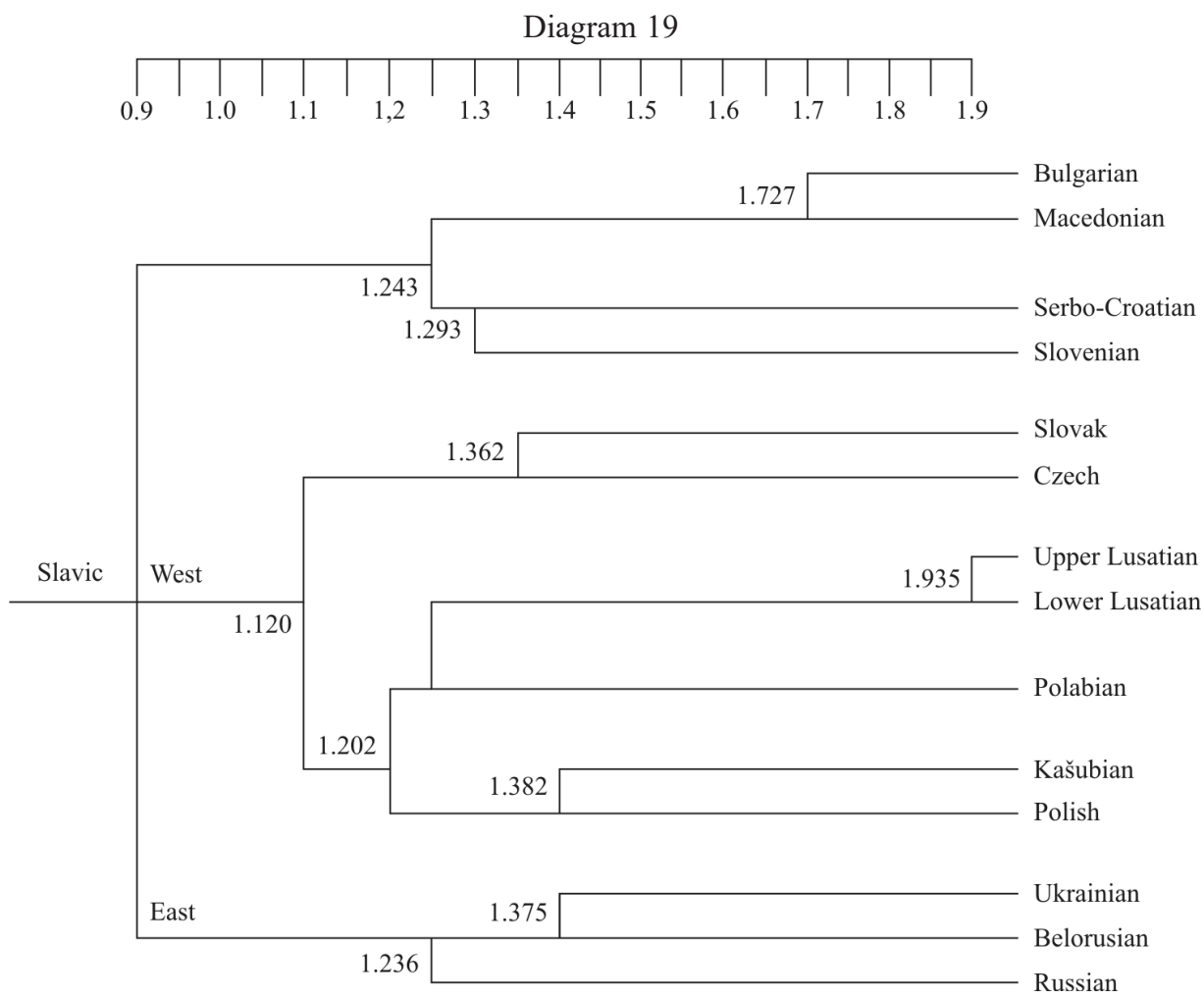

Žuravlev (1993) applied the same method to the Old Novgorodian (Krivičian) dialect. In agreement with expectations he obtained the highest correlation with old literary languages with incomplete lexicons (Old Church Slavonic, Polabian, Old Russian). Among modern languages the first three positions were occupied by Lower Sorbian, Kašubian-Slovincian, and Upper Sorbian in this order. So this lexicostatistic test supported the hypotheses of a Lekhitic component in the Northwest of the Slavic dialect continuum.

\section{GLOTTOCHRONOLOGY}

Besides lexicostatistics, glottochronology was also applied by various scholars to the Slavic languages. Let us begin with the attempts based on the standard Swadesh variant.

Hincha 1962 
One of the first attempts to apply the 'classical' method, developed by Swadesh and termed glottochronology by him, was presented by Hincha (1962). Unfortunately, he did not publish his wordlists, only the final percentages. His results (on the left side), based only on 5 languages, can be projected into Diagram 20, indicate the closer East \& West Slavic unity. On the other hand, the method of the highest means does not confirm the South Slavic unity - concretely, Serbo-Croatian is closer to West Slavic than to Bulgarian according to him.

Table 2

\begin{tabular}{|c|c|c|c|c|}
\hline & SC. & Cz. & Pol. & Rus. \\
\hline Bul. & 72 & 72 & 66 & 69 \\
\hline SC. & & 82 & 73 & 71 \\
\hline Cz. & & & 87 & 81 \\
\hline Pol. & & & & 78 \\
\hline
\end{tabular}

Diagram 20

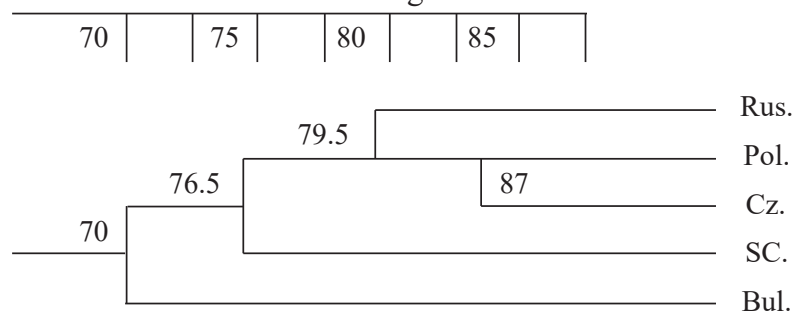

\section{Čejka 1972}

One of the most detailed attempts to apply 'classical glottochronology' to the Slavic languages is from the Czech slavicists A. Lamprecht \& M. Čejka (1963) and Čejka himself (1972). In his study from 1972 Čejka compiled the 100-word-lists from 12 living languages. His results are concentrated in the table 5 (the figures are\%):

Table $3 \mathrm{a}$

\begin{tabular}{|c|c|c|c|c|c|c|c|c|c|c|c|}
\hline & Mac. & SC. & Sln. & Slk. & Cz. & ULus. & LLus. & Pol. & Blr. & Ukr. & Rus. \\
\hline Bul. & 86 & 80 & 76 & 75 & 74 & 73 & 71 & 74 & 77 & 72 & 74 \\
\hline Mac. & & 84 & 75 & 76 & 75 & 76 & 73 & 71 & 74 & 71 & 70 \\
\hline SC. & & & 85 & 80 & 79 & 77 & 74 & 75 & 77 & 73 & 71 \\
\hline Sln. & & & 80 & 84 & 78 & 78 & 79 & 76 & 71 & 74 \\
\hline Slk. & & & & 92 & 86 & 87 & 85 & 80 & 76 & 74 \\
\hline Cz. & & & & & 87 & 87 & 81 & 77 & 73 & 74 \\
\hline ULus. & & & & & & 94 & 80 & 78 & 74 & 74 \\
\hline LLus. & & & & & & & & 83 & 78 & 74 & 73 \\
\hline Pol. & & & & & & & & & 80 & 76 & 77 \\
\hline Blr. & & & & & & & & & & 92 & 86 \\
\hline Ukr. & & & & & & & & & & & 86 \\
\hline
\end{tabular}

The following step consists in the determination of the closest pairs or groups of languages. The pairs (or triads etc.) with the highest grade of relationship will serve 
as the base of comparison, leading to the deeper past. The order of the first closest pairs is: ULus. + LLus. (= Lus.) 94\%, Cz.+ Slk. (= Czsl.) 92\%, Blr.+ Ukr. 92\%, Rus. + [Blr. + Ukr.] (= ESl.) 86\%, Bul. + Mac. 86\%, SC. + Sln. 85\%.

Table $3 b$

\begin{tabular}{|c|c|c|c|c|c|}
\hline & SC. + Sln. & CzSlk. & Lus. & Pol. & ESl. \\
\hline Bul. + Mac. & 78.8 & 75.0 & 73.3 & 72.5 & 73.0 \\
\hline SC. + Sln. & & 80.8 & 76.8 & 77.0 & 73.7 \\
\hline Cz. + Slk. & & & 86.8 & 83.0 & 75.7 \\
\hline U + LLus. & & & & 81.5 & 75.2 \\
\hline Pol. & & & & & 77.7 \\
\hline
\end{tabular}

It is apparent that the West Slavic languages form a branch consisting of Polish and the compact unit of Lusatian and Czech-Slovak, considering the high score $86.75 \%$ between the latter subgroups. Slovenian is in a special position between Serbo-Croatian (85\%) and Czech (84\%). Naturally, it is not possible to separate Czech and Slovak. That is why it is necessary to evaluate the Czech-Slovenian relation from the Czech-Slovak perspective. The average of Czech-Slovak vs. Slovenian scores is $82 \%$, and it is less than $85 \%$ for Slovenian vs. Serbo-Croatian on the one hand, still less than the average for all 5 West Slavic languages (86.2\%), and even less than the average of the lowest scores within West Slavic, Polish vs. Lusatian and Polish vs. Czech-Slovak, namely $(83.0+81.5) \% / 2=82.3 \%$. And so it is necessary to accept the traditional affiliation of Slovenian together with Serbo-Croatian, although the position of Slovenian is more or less transitional. Interesting are the almost equal common proportions of cognates between West Slavic \& Slovenian-Serbo-Croatian (78.4\%) and Slovenian-Serbo-Croatian \& Bulgar-Macedonian (78.8\%), indicating a common Southwest Slavic dialect continuum, although the result $73.8 \%$ for the West Slavic branch and Bulgar-Macedonian is lower than the average score $75.9 \%$ for West and East Slavic and very close to $73.1 \%$ between South and East Slavic. This lowest result and the common arithmetic average $74.6 \%$ between East and Southwest Slavic define the period of the disintegration for all Slavic languages. Čejka's results may be depicted by the following tree-diagram (Čejka did not present any diagram of this type, but his data became a source for the diagram created by Girdenis \& Mažiulis 1994, 11; the model of divergence presented here is based on the preceding discussion): 
Diagram 21
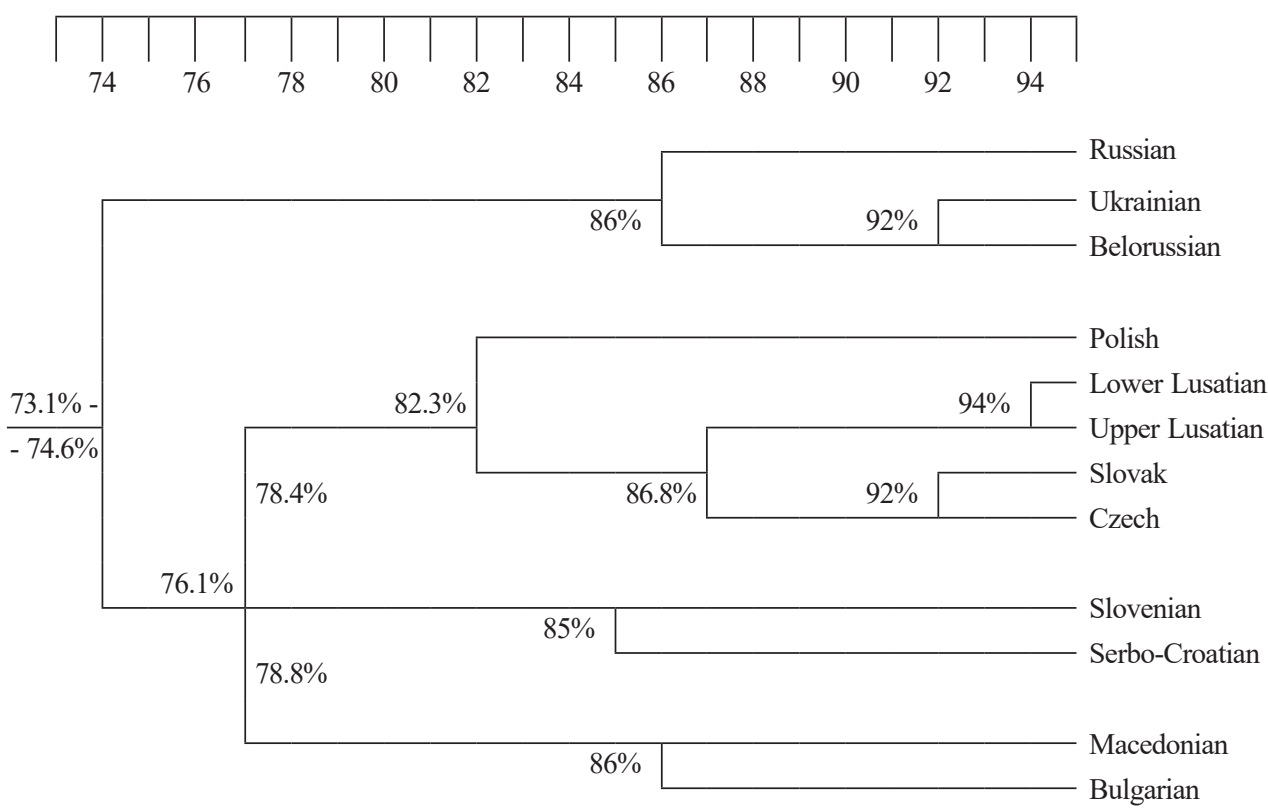

Vollmer apud Tischler 1973

Another scholar who tried to apply 'classical glottochronology' to the Slavic languages, was the German J. Vollmer. His results were published by Johann Tischler in his monograph Glottochronologie und Lexikostatistik (Innsbruck 1973, 133). Vollmer compared 6 modern Slavic languages, plus Old Church Slavonic (his wordlists were not published):

Table 4

\begin{tabular}{|c|c|c|c|c|c|c|}
\hline & Bul. & SC. & Slk. & Cz. & Pol. & Rus. \\
\hline OCSl. & 75 & 81 & 80 & 81 & 78 & 80 \\
\hline Bul. & & 81 & 81 & 74 & 72 & 74 \\
\hline SC. & & & 82 & 77 & 77 & 77 \\
\hline Slk. & & & & 86 & 81 & 79 \\
\hline Cz. & & & & & 86 & 76 \\
\hline Pol. & & & & & & 74 \\
\hline
\end{tabular}

Abstracting from Old Church Slavonic as an extinct literary language, Vollmer's results can be depicted as follows: 
Diagram 22
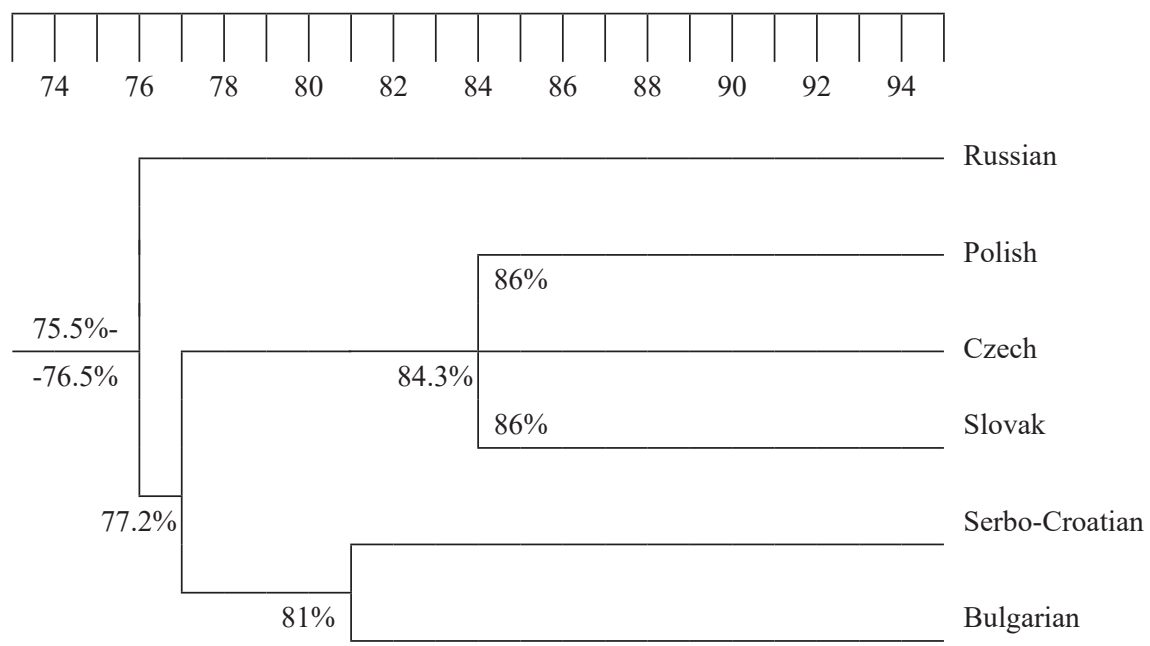

It is apparent that the topology of the diagram based on Vollmer's data is in principle in good agreement with Čejka' results, perhaps only the equality of Czech-Slovak and Czech-Polish is rather surprising. But both models, translated into the absolute chronology according to Swadesh's scenario, give too young, and thus ahistorical, results: Čejka $(74 \pm 1) \%$, i.e. AD 1000, Vollmer $(75 \pm 0.5) \%$, i.e. AD 1050 as the date of disintegration of the Slavic languages.

Let us compare the results based on 'classical glottochronology' with the results reached by applying the recalibrated glottochronology:

The first model was developed directly by Sergei Starostin with his team. We are grateful to him for unpublished data from his database.

Table 5

\begin{tabular}{|c|c|c|c|c|c|c|c|c|c|c|c|c|}
\hline & Mac. & SC. & Sln. & Slk. & Cz. & ULus. & LLus. & Plb. & Pol. & Br. & Ukr. & Rus. \\
\hline Bul. & 90 & 88 & 84 & 82 & 81 & 75 & 75 & 77 & 80 & 82 & 76 & 80 \\
\hline Mac. & & 90 & 83 & 79 & 82 & 79 & 79 & 83 & 81 & 84 & 78 & 81 \\
\hline SC. & & & 93 & 89 & 89 & 83 & 82 & 88 & 86 & 88 & 82 & 84 \\
\hline Sln. & & & & 87 & 90 & 82 & 81 & 88 & 86 & 85 & 79 & 85 \\
\hline Slk. & & & & & 91 & 85 & 87 & 85 & 90 & 91 & 85 & 83 \\
\hline Cz. & & & & & & 89 & 88 & 88 & 88 & 87 & 80 & 82 \\
\hline ULus. & & & & & & & 96 & 89 & 85 & 86 & 78 & 80 \\
\hline ULus. & & & & & & & & 90 & 89 & 86 & 79 & 80 \\
\hline Plb. & & & & & & & & & 87 & 86 & 81 & 83 \\
\hline Pol. & & & & & & & & & & 90 & 85 & 85 \\
\hline Blr. & & & & & & & & & & 97 & 92 \\
\hline Ukr. & & & & & & & & & & & & 88 \\
\hline
\end{tabular}


Classification of the Slavic languages after S. Starostin (presented in Santa Fe, NM, USA, March 2004)

\section{Diagram 23}

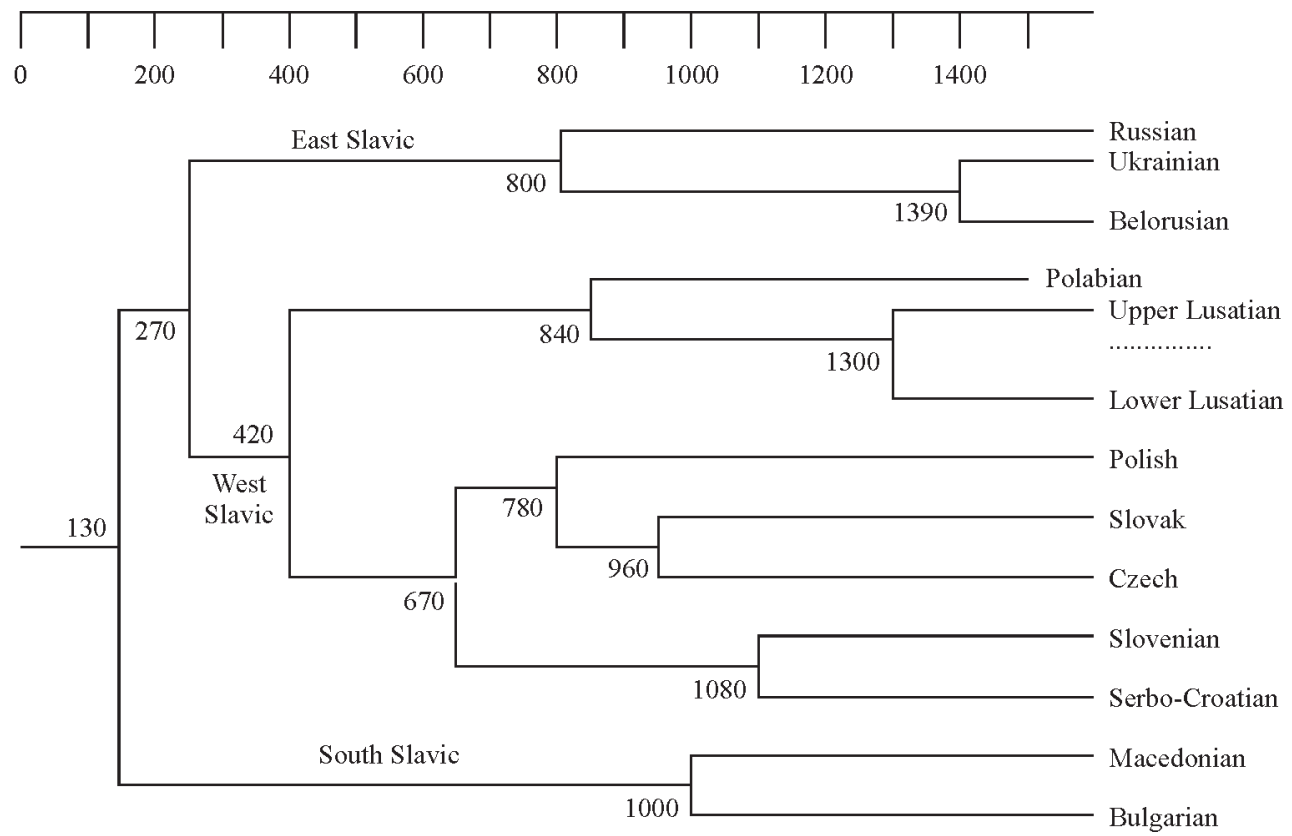

The present tree-diagram was generated by a computer program prepared by Sergei Starostin in the late 1980s. A preliminary version of this model was published in Starostin's article Methodology of Long-Range Comparison, which was first published in the volume Nostratic, Dene-Caucasian, Austric and Amerind, ed. V. Shevoroshkin, Bochum 1992, 78, and later reproduced in the volume Historical Linguistics \& Lexicostatistics, ed. V. Shevoroshkin \& P.J. Sidwell, Melbourne 1999, s. 65. The first version of the diagram still operated with the trichotomy, opposing East, West and South branches, but the last without Slovenian and Serbo-Croatian, which were classified together with the West branch.

The second model based on the 'recalibrated glottochronology' was prepared by Novotná (2004), Novotná \& Blažek (2005, 2007, 2008) and Blažek (2016a, b). The word-lists cover 15 modern idioms, plus Polabian and Old Church Slavonic. Contrary to Starostin our calculation was realized 'manually', not via any computer program, but in agreement with the rules formulated by Starostin. The only methodological difference from Starostin consists in the systematic inclusion of synonyms. Swadesh postulated choosing only so called 'main' synonyms, the most frequent equivalents of concrete semantic units. But if there are several synonyms and some of them are related, the degree of the mutual genetic relationship is higher. And so it is not correct to eliminate synonyms. That is why we operate with 100 semantic 
units, while the number of the lexical units is usually higher. From our personal communication we know that Starostin also operated with synonyms, but not systemically. He also did not explain how to calculate with them. Our strategy is based on the standard list of 100 semantic units chosen already by Swadesh in 1955. The number of semantically identical and unborrowed units, attested in both compared languages corresponds to $100 \%$. The numerator in our proportion is represented by the number of all cognates, including synonyms.

Our results are summarized in Table 6a:

Table 6a

\begin{tabular}{|c|c|c|c|c|c|c|c|c|c|c|c|c|c|c|c|}
\hline & Bul. & Mac. & Srb. & Cr. & Sln. & Slk. & Cz. & ULus. & LLus. & Plb. & Kaš. & Pol. & Blr. & Ukr. & Rus. \\
\hline OCS1. & 83.6 & 84.6 & 87.3 & 88.3 & 85.5 & 88.4 & 92.2 & 87.3 & 85.4 & 83.0 & 83.2 & 85.4 & 84.3 & 79.6 & 82.7 \\
\hline Bul. & & 95.0 & 91.9 & 92.0 & 87.0 & 85.9 & 85.9 & 86.9 & 84.8 & 79.6 & 83.5 & 84.8 & 84.5 & 78.8 & 83.0 \\
\hline Mac. & & & 92.9 & 94.0 & 89.0 & 85.9 & 85.9 & 86.9 & 84.8 & 81.8 & 83.5 & 84.8 & 84.5 & 81.8 & 84.0 \\
\hline Srb. & & & & 100 & 94.9 & 86.7 & 87.8 & 86.7 & 85.7 & 82.7 & 85.4 & 84.7 & 85.4 & 80.6 & 81.8 \\
\hline Cr. & & & & & 97.0 & 89.9 & 91.9 & 89.9 & 88.9 & 87.4 & 87.6 & 87.9 & 86.6 & 82.8 & 85.0 \\
\hline Sln. & & & & & & 87.9 & 90.9 & 87.9 & 87.9 & 86.7 & 84.8 & 87.9 & 84.5 & 79.8 & 83.0 \\
\hline Slk. & & & & & & & 96.0 & 90.9 & 88.9 & 81.9 & 86.7 & 90.8 & 86.5 & 82.7 & $86: 9$ \\
\hline Cz. & & & & & & & & 91.9 & 89.9 & 86.7 & 89.6 & 90.8 & 87.5 & 82.7 & 86.9 \\
\hline ULus. & & & & & & & & 99.0 & 88.5 & 92.7 & 92.9 & 88.5 & 84.7 & 87.9 \\
\hline LLus. & & & & & & & & & 85.2 & 90.6 & 91.8 & 87.5 & 82.7 & 86.9 \\
\hline Plb. & & & & & & & & & & & 84.8 & 86.3 & 82.4 & 82.7 & 81.8 \\
\hline Kaš. & & & & & & & & & & & & 100 & 86.2 & 83.3 & 83.5 \\
\hline Pol. & & & & & & & & & & & & & 88.5 & 83.7 & 85.9 \\
\hline Blr. & & & & & & & & & & & & & & 99.0 & 93.8 \\
\hline Ukr. & & & & & & & & & & & & & & & 91.9 \\
\hline
\end{tabular}

In the following steps we will abstract from Old Church Slavonic as an old literary (and rather artificial) language with an incomplete lexical corpus (the same may be said about Polabian; for this reason its results are rather problematic). The unexpectable share of $92.2 \%$ connecting Old Church Slavonic with Czech requires a special explanation which is not a subject of the present study (cf. Veprek 2006). Let us order the languages in groups, usually in pairs, according to languages with the closest relationship: Srb.-Cr. (= SC.) and Kaš.-Pol. agree in 100\%; regarding the different distribution of synonyms, they will be taken into account separately. Further ULus.-LLus. (= Lus.) 99\%, Blr.-Ukr. 99\%, Cz.-Slk. 96\%, SC.-Sln. 96\%, Bul.-Mac. 95\%. The comparison of Russian vs. Belorussian \& Ukrainian gives 92.9\%, indicating the East Slavic (= ESl.) unit. 
Table $6 \mathrm{~b}$

\begin{tabular}{|c|c|c|c|c|c|c|}
\hline & SC.-Sln. & Cz.-Slk. & Lus. & Plb. & Kaš.-Pol. & ESl. \\
\hline Bul.-Mac. & 91.1 & 85.1 & 85.9 & 80.7 & 84.2 & 82.8 \\
\hline SC.-Sln. & & 89.2 & 87.8 & 85.6 & 86.4 & 83.3 \\
\hline Cz.-Slk. & & & 90.4 & 84.3 & 89.7 & 85.3 \\
\hline Lus. & & & & 86.9 & 92.0 & 86.4 \\
\hline Plb. & & & & & 85.6 & 82.3 \\
\hline Kaš.-Pol. & & & & & & 85.2 \\
\hline
\end{tabular}

The East Slavic unit was already defined. It is apparent that the South Slavic unit with the average score $91.1 \%$ in the test lexicon may be postulated too. It is more than $89.2 \%$ between SC.-Sln. and Cz.-Slk. For the existence of the West Slavic (=WS1.) unit there are also the arguments: $90.7 \%$ without Polabian, $89.0 \%$ including Polabian. The final step is the comparison of the South, West and East branches of Slavic, in table 6c/left without Kašubian, in table 6c/right with Kašubian:

Tables $6 \mathrm{c}$

\begin{tabular}{|c|c|c|}
\hline left & WSl. & ESl. \\
\hline SSl. & 86.8 & 83.1 \\
\hline WSl. & & 85.7 \\
\hline
\end{tabular}

\begin{tabular}{|c|c|c|}
\hline right & WS1 & ESl. \\
\hline SSl. & 86.4 & 83.1 \\
\hline WSl. & & 85.2 \\
\hline
\end{tabular}

Although the differencies between SSl.-WS1. (86.8/86.4\%) and WS1.-ES1. $(85.7 / 85.2 \%)$ are not too big, they allow us to modify the traditional trichotomic classification of the Slavic languages. In contrary to the usual three equidistant units it is necessary to introduce a hierarchic model with a sequence of two dichotomies. The first division separated the ancestors of the East and Southwest Slavic dialects, the second division separated West and South Slavic. The average of the South-West vs. East scores gives the result $84.7 \%$ without Polabian and $84.6 \%$ with Polabian. So the disintegration of the Slavic dialect continuum should be defined by this figure $(84.7 \%)$ and the value of the lowest result $83.1 \%$, reached for South and East Slavic. Translated into absolute chronology calibrated by Starostin, it is possible to date the disintegration of the Slavic languages between AD 520 and 600. The West and South Slavic languages were separated in the beginning of the 8th cent., West Slavic disintegrated around AD 900, South Slavic in the middle of the 10th cent. and East Slavic around AD 1070. The closest relatives of Polabian are Lusatian (86.9\%), Czech (86.7\%; but with Slovak only 81.8\%), Polish-Kašubian (85.6\%), Serbo-Croatian-Slovenian $(85.6 \%)$. The average score between Polabian vs. West Slavic and Serbo-Croatian \& Slovenian, namely $85.6 \%$, indicates that the position of Polabian could be between them or that the ancestor of Polabian separated even a little earlier. 
The mutual relations are depicted in Diagram 24:

Diagram 24

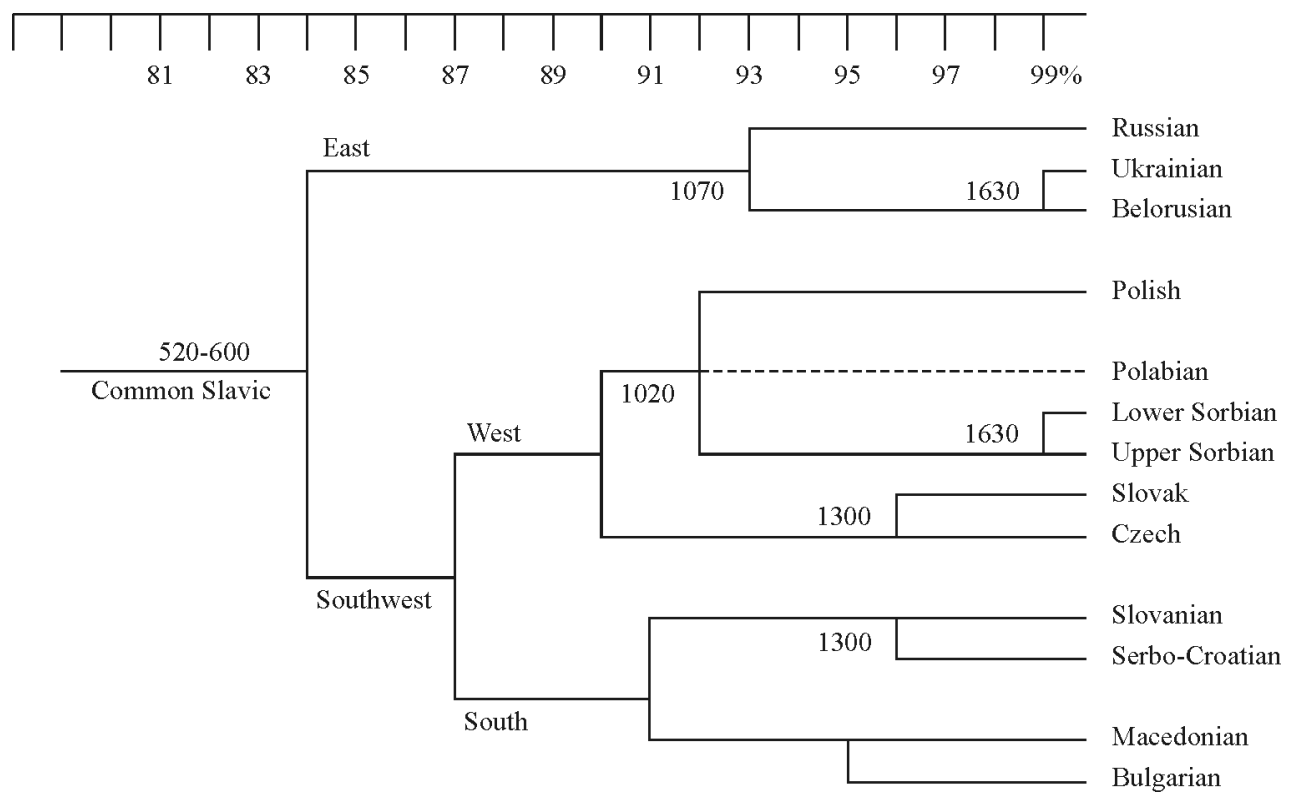

Chain model

The figures from Tables $6 \mathrm{a} \& \mathrm{~b}$ may also be used to construct an alternative model describing the mutual relations between the Slavic languages, which can be called the 'dialect chain' model. This chain appears, if we order the closest idioms in the direct neighborhood:

$$
\begin{array}{clr}
\text { LLus. } & \text { Plb. } & \text { Ukr. } \\
99 \mid & \mid 88.5 & \mid 99
\end{array}
$$

Bul.-95-Mac.-94-Cr.-97-Sln.-91-Cz.-92-ULus.-93-Pol.-88.5-Blr.-94-Rus.

|96

Slk.

The scheme is more linear, if the common units Serbo-Croatian, Czech-Slovak, Lusatian, Kašubian-Polish and Belorussian-Ukrainian are taken in account (Polabian was left aside for its incomplete lexicon).

Bul.-95-Mac.-93.5-SC.-96-Sln.-89-Cz.+Slk.-90.5-Lus.-90.5-Pol.-86-Blr.+Ukr.-93-Rus.

Only in two cases do the figures fall under $90 \%$. It is symptomatic that the lowest values indicate the limits between the south and west branches (89\%) and west and east branches $(86 \%)$. This means that this alternative approach gives the same results as the preceding steps, i.e. the divergence of the Slavic languages can be described as 
a sequence of two dichotomies: (1) east vs. southwest (6th cent.); (2) south vs. west (beginning of the 8th cent.).

\section{Conclusion}

The present study summarizes most of the models of classification of the Slavic languages, which have been formulated till the present time. For their easier comparison the conclusions of various authors were transformed into tree-diagrams, if they were not proposed already in this form. In total, 21 models of classification of the Slavic languages are collected and compared here, many of which were created for this study from their verbal description or enumeration. With regard to the apparent close relationship of the Slavic languages, it seems to be a surprisingly high number. Let us compare the results and arrange them according to their common features and with regard to methodologies used.

The qualitative models with the highest number of units, namely Ivanov's heptachotomic, Jakubinskij's hexachotomic and Kopečný's pentachotomic schemes, reflect a minimalistic approach, if they operate only with the lowest genetic units, whose identity is (at least for the authors) unquestionable, without any attempt at determination of a higher hierarchy in their mutual relations. Both the presented tetrachotomic models preserve the East and West branches, only instead of the South Slavic branch they operate with two units, Bulgar-Macedonian and Slovenian-Serbo-Croatian. The most frequent trichotomic model works with three more or less equal branches: East, West and South. Such a conclusion also follows from the results of Žuravlev with his application of lexicostatistics. The dichotomic models, operating with the qualitative approach, usually place in opposition the West versus South \& East branches (Dobrovský, Schleicher, Holub \& Kopečný, Bernštajn, etc.), less frequently South versus West \& East (Križanić, Mareš). It is remarkable that the application of glottochronology leads to different conclusions. According to Starostin the first separation should be ascribed to the Bulgarian-Macedonian branch. This conclusion agrees only with the results of Hincha, although he worked only with 5 languages. Other results (Vollmer, Čejka, Novotná \& Blažek) indicate the sequence of two dichotomies: 1. East vs. West \& South; 2. West vs. South. However, these results also allow us an alternative conclusion, that the South branch might represent an outcome of secondary convergence of already separated Slovenian-Serbo-Croatian and Bulgarian-Macedonian branches - cf. the lower score between Slovenian and Bulgarian-Macedonian (ø88\%) versus Slovenian-Serbo-Croatian (ø96\%). The Slovenian-Bulgar-Macedonian result even yields to the separate score between Slovenian and Czech \& Slovak (ø90.5\%). In any case it is apparent that the qualitative approaches to classification frequently give different conclusions than the quantitative methods. One possible explanation could consist in a hypothesis that the development of phonological or morphological systems need not copy the dynamics of changes of lexicon and the whole process of divergence at all. Concretely, the similar phonological or morphological features need not reflect shared innovations, but independently inherited archaisms or results of parallel, independent processes. Let us mention as an 
example of the independently inherited archaism e.g. the preservation of the nasal vowels in Polish and some Macedonian dialects or dual in both the Lusatian languages and Slovenian. The spirantisation $*_{g}>h$ in Ukrainian, Belorussian, Slovak, Czech and Upper Sorbian is also not a reason to formulate a specific taxonomic unit from the given languages. Although this change was realized more or less synchronically at the turn of the 12th and 13th centuries (Lamprecht 1987, 176-77), it is a long time after constitution of main borders between the Slavic dialects. Now let us judge some of principal arguments supporting the unity of the East and South Slavic branches. One of them is so-called l-epentheticum, appearing between labials and $j$ in East and South Slavic. But the absence of this feature in the West Slavic literary languages need not imply that it did not exist in the pre-literary era. As an indirect witness of the early $l$-epentheticum also in the West Slavic branch may serve the Czech toponyms of the type Davle, Hostovlice, Chodovlice, Libel, Liblice, Liblin, Počeplice, Roblin, Skřipel, Třebivlice, Třebovle, Tuchlovice, Vidovle, Žitovlice, etc. (Vondrová \& Blažek 2001, 318-21), situated in the oldest Czech settlement area, likewise Slovak toponyms such as Chlevl'any, Rybl'any (Shevelov 1964, 221) or Polish as Chraplewo, Chrzablice, Deblin, Demlino, Droblino, Drogowle, Dyblino, Dymlin, Dziwle, Grąblice, Grębliny, Konotopla, Kruplino, Lubla, Luble, Lublewa, Lublewo, Lublin, Paplino, Polplin, Rąblów, Rzeplice, Sęplino, Sowliny, Szumlino, Trawlica, Treblina, Trzeblewicy, Tumlin, Wablany, Witowla, Zęblewo, Zięblice, Ziemlice, Ziemlin etc. (Karpluk 1964, 33-41). The secondary elimination of the $l$-epentheticum is historically actually attested, namely in the development of Bulgarian and Macedonian, while in Old Church Slavonic the $l$-epentheticum was consistently preserved. The most natural solution is the conclusion that the $l$-epentheticum represents a common Slavic archaism and not a specific Southeast Slavic innovation (cf. Blažek 2008). Another argument for the Southeast Slavic unity should be the simplification of the clusters * $d l$, $t l>l$. But this feature also is not without exceptions. In the northern periphery, in the Old Novgorodian tribal dialect of Krivičians there are continuants $g l, k l$, just as in the Kašubian-Slovincian dialects. In both cases it could be ascribed to an influence of the Baltic substratum. In the southwest periphery, in the Zilyan dialects of Slovenian, the clusters $d l \& t l$ are preserved (cf. also the form modliti se from Frisingian fragments, against the modern form móliti "to pray"). In standard Slovenian the dental element is preserved at least in participles of the type pâdel, pádla "he, she has fallen", cvetèl, cvetlà "he, she has bloomed", similarly in the Serbian dialect from the river Timok: iskrádla "she has stolen", uplétle "they have woven". On the other hand, in Lower Sorbian such forms as sato "lard", etc. appear (Shevelov 1964, 371-72). It seems that the process of simplification was not synchronic in the whole Southeast Slavic area, but at different tempos in various places of the Slavic dialect continuum. The discussion about concrete arguments may be finished with the conclusion that both of the arguments from historical phonetics, which seem to support a closer Southeast Slavic relationship, are neither exclusive, nor unambiguous. Still more problematic conclusions follow from a use of morphology as a main tool of the genetic classification. W. Mańczak (1992, 23-29) mentioned the paradoxical results of comparison of related languages, if those with conservative and reduced inflection are compared. In this perspective e.g. Polish stands closer to Lithuanian than to Bulgarian, Gothic closer to 
Latin than to English etc. It is possible to agree with Mańczak that the genetic classification of related languages with full documentation should be mapped predominantly on the basis of etymological analysis of lexicon and its statistical evaluation, while the phonologic and morphologic isoglosses play a supplementary role. On the other hand, in the case of fragmentarily attested languages the historical phonology and morphology are frequently the only ways to determine their positions in genetic classification.

\section{Discussion of the present results in historical perspective}

Applying the standard Swadesh glottochronological test (Hincha, Čejka, Vollmer, also e.g. Fodor), the extremely recent data result of the disintegration of Slavic, namely AD 800-1100, apparently does not agree with known historical facts. On the other hand, Starostin dated the beginning of this process too early, namely to AD 130. But the historical sources and archaeology register the first migrations of Slavs only during the 6th cent. (Třšstík 1997, 17-53). Concretely, in the mid of the 6th cent. the Gothic historian Jordanes and his Byzantine colleague Procopius mentioned the first activities of the Slavic tribes in North Balkan and adjacent territories in the north and east. Let us repeat their witness.

Jordanes, Getica $\S 34-35$ :

Introrsus illis Dacia est, ad coronae speciem arduis Alpibus emunita, iuxta quorum sinistrum latus, qui in aquilone vergit, ab ortu Vistulae fluminis per immensa spatia Venetharum natio populosa considet. Quorum nomina licet per varias familias et loca mutentur, principaliter tamen Sclaveni et Antes nominantur. Sclaveni a civitate Novitunense et lacu qui appellatur Mursiano usque ad Danastrum et in boream Viscla tenus commorantur: hi paludes silvasque pro civitatibus habent. Antes vero, qui sunt eorum fortissimi, qua Ponticum mare curvatur, a Danastro extenduntur usque ad Danaprum, quae flumina multis mansionibus ad invicem absunt.

(34) Within these rivers lies Dacia, encircled by the lofty Alps as by a crown. Near their left ridge, which inclines toward the north, and beginning at the source of the Vistula, the populous race of the Venethi dwell, occupying a great expanse of land. Though their names are now dispersed amid various clans and places, yet they are chiefly called Sclaveni and Antes. (35) The abode of the Sclaveni extends from the city of Noviodunum and the lake called Mursianus to the Danaster, and northward as far as the Vistula. They have swamps and forests for their cities. The Antes, who are the bravest of these peoples dwelling in the curve of the sea of Pontus, spread from the Danaster to the Danaper, rivers that are many days' journey apart."

See The Gothic history of Jordanes in English version with an introduction and a commentary by Charles Christopher Mierow. Princeton: University Press - London: Humphrey Milford

- Oxford: University Press 1915.

Christensen, Arne Søby. 2002. Cassiodorus Jordanes and the History of the Goths. Studies in a Migration Myth. University of Copenhagen: Museum Tusculanum Press. $<$ https://people. ucalgary.ca/ vandersp/Courses/texts/jordgeti.html $>$

If Jordanes mentioned Venethi living near the left ridge of the Dacian Alpes, i.e. Carpathian mountains, and the source of the Vistula river, he probably meant the 
Common Slavs. He knew their descendants, Sclaveni, located to the west of the Dniester, and Antes, located to the east of the Dniester.

In his book YПЕР T $\Omega \mathrm{N}$ ПО $\Lambda$ EM $\Omega \mathrm{N} \Lambda \mathrm{O} Г \mathrm{O}$ Procopius of Caesarea differentiated only

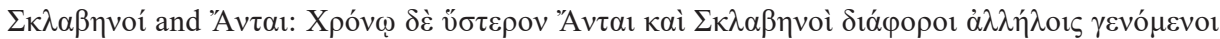

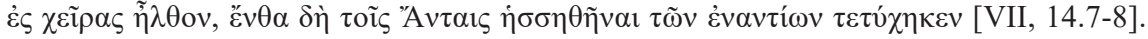

„But later on the Antae and Sclaveni became hostile to one another and engaged in a battle, in which it so fell out that the Antae were defeated by their opponents."

But he was sure that they used the same language:

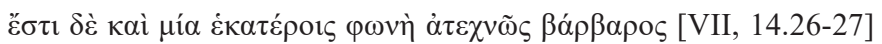

„And both the two peoples have also the same language, an utterly barbarous tongue".

Cf. further about their ethnic unity:

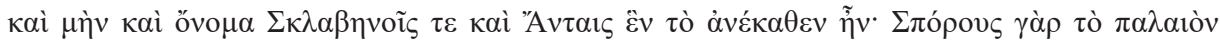

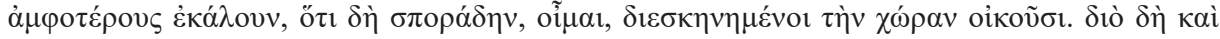

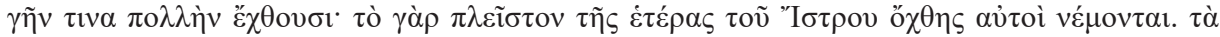

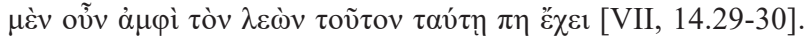

„In fact, the Sclaveni and Antae actually had a single name in the remote past; for they were both called Spori in olden times, because, I suppose, living apart one man from another, they inhabit their country in a sporadic fashion. And in consequence of this very fact they hold a great amount of land; for they alone inhabit the greatest part of the northern bank of the Ister. So much then may be said regarding these peoples" (translated by H.B. Dewing).

The information of both the authors may be interpreted so that the Venethi, living originally to the north of the Carpathian mountains and around the source of the Vistula river, disintegrated into the western Sclaveni and eastern Antes/Antae. During their move to the south their border probably became the \{upper\} Dniester. With respect to the location of Antes/Antae between the Dniester and Dnieper, it is tempting to identify them with the East Slavs (cf. e.g. Niederle 1953, 145-47; Nalepa 1968, 111), whose separation from the Slavic dialect continuum was dated to the 6th cent. in our glottochronological test. The Sclaveni could represent the still undifferentiated Southeast Slavs, whose disintegration is dated only to the beginning of the 8th cent. according to our results.

In several historical sources there were described the migrations of the Slavic populations, whose starting-point was located to Croatia, sometimes called 'Great'. The notice of Constantine Porphyrogenitus (c. 950 CE) about location of both the Croatian and Serbian homelands and Great Croatia beyond Hungary $(\S \S 31,32$ - see below), seen from the Byzantine perspective, leads to the north from the Danube.

\section{Constantine Porphyrogenitus: De administrando imperio $§ 32$ (written AD 948-952)}

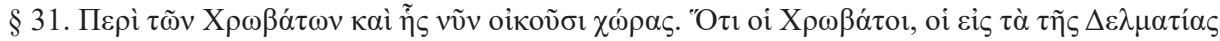

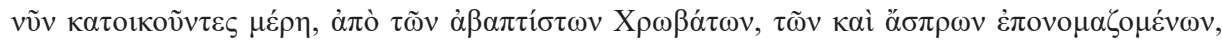

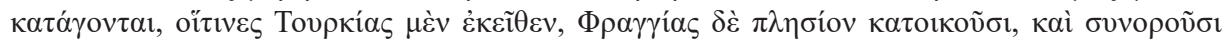

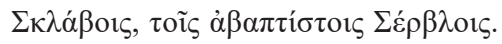


$\S 31$. „The Croats who now live in the region od Dalmatia are descended from the unbaptized Croats, also called 'white', who lived beyond Turkey $\{=$ Hungary $\}$ and next to Francia, and have for Slav neighbors the unbaptized Serbs."

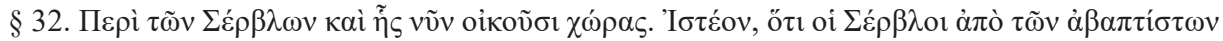

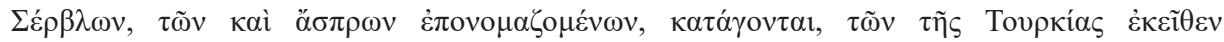

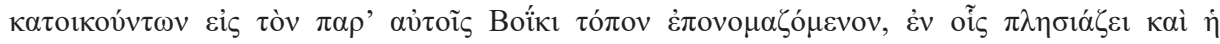

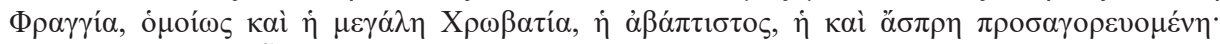

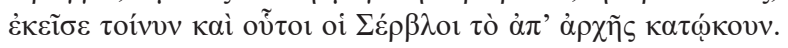

$\S 32$. „Of the Serbs and of the country they now dwell in. The Serbs are descendants from unbaptized Serbs, also called 'White', who live beyond Turkey \{= Hungary $\}$ in a place called by them Boïki, where their neighbour is Francia, as is also Great Croatia, the unbaptized, also called 'White'; in this place, then, these Serbs also originally dwelt."

These 'Northern Croatians' have been localized along the present Czech-Polish border, including Silesia and the area around the upper stream of the Vistula according to several independent sources:

(1) 'Alfred's Orosius', i.e. the Old English description of Central and North Europe, including Ohthere's voyage around Scandinavia and Wulfstan's voyage along the south shores of the Baltic Sea, added to the Old English translation of Historiae Adversus Paganos by Paulus Orosius, initiated by Alfred the Great around $890 \mathrm{CE}$ ):

Ond be eastan Maroara londe is Wisle lond. Ond be eastan poem sint Datia, pa pe iu wceron Gotan. Be norpaneastan Maroara sindon Dalamentsan. Ond be eastan Dalamentsan sindon Horigti. Ond be norpan Dalamentsan sindon Surpe; ond be westan him Sysyle. Be norpan Horoti is Magpa land; ond be norpan Maegp londe Sermende op pa beorgas Riffen.

King's Alfred Orosius, Old-English text and Latin original, edited by Henry Sweet. London: Trübner 1883, 16. https://ia800202.us.archive.org/21/items/kingalfredsorosi79oros/kingalfredsorosi79oros.pdf

„To the east of Maroaro \{= Moravia\} is Wisleland \{country along the Vistula\}, and to the east of that is Datia $\{=$ Dacia $\}$, though it formerly belonged to the Goths $\{=$ probably not only Eastern Balkan, but also Western Ukraine\}. To the north-east of Maroaro \{= Moravia\} are the Dalamensæ $\{=$ Daleminci / Glomaci\}, east of the Dalamensæ are the Horigti $\{=$ Croatians , and north of the Dalamensæ are Surpe $\{=$ Sorbi of Lusatia\}, to the west also are Sysele. To the north of the Horoti/Horiti $\{=$ Croatians\} is Mægthaland \{= Mazovia?\}, and north of Mægthaland is Sermende $\{=$ Sarmatian country $\}$, quite to the Riphæan mountains."

The Anglo-Saxon Version from the historian Orosius, Alfred the Great. Together with an English translation from the Anglo-Saxon by Daines Barrington. London: Bowyer \& Nichols 1773, 8-9.

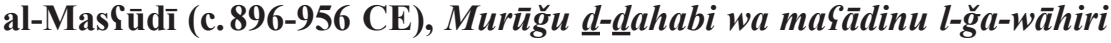 'Meadows of Gold and Mines of Gems' (written in 947 CE)}

Tumma ğinsun yuqālu lahu $M_{-} r a \bar{w}{ }_{-} t \underline{t}$ tumma ğinsun yuqālu lahu $H_{-} r_{-}$wātīn_tumma ğinsun yuqālu

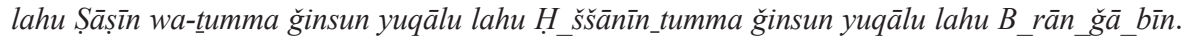


„Then the tribe called $*$ Moravbtji $\{$ Moravians\}, after that the tribe called $*$ Xorvati $\{$ Croatians\}, then the tribe called *Sasi \{Saxons; the final $-\bar{i} n$ reflects the Slavic singulative in $*_{\text {-in }}$ \} and the tribe called $* X y z j a n e$ \{one of tribes of Poland , after that the tribe called $* B r a-$ ničevbtji \{one of the Slavic tribes from Pannonia, probably including Slovakia\} or *Pragjane? \{inhabitants of Praga in Bohemia or in Poland?\}".

Ivan Hrbek, in Magnae Moraviae Fotes Historici, III: Diplomata, epistolae, textus historici varii, ed. by Dagmar Bartoňková \& Radoslav Večerka. Praha: Koniasch Latin Press 2011, 363-64.

\section{Yōsippōn, the Hebrew chronicle written in Italy in the mid of the 10th cent. $\mathrm{CE}$}

wgm Mwr?w? w-Krwt ?y w-Swrbyn w-Lwcnyn w-Lz?nyn [or Lwwmyn / Lyybnyn / Lywmn] $w$-Kr?kr w-Bzymyn [with the conjecture Bwymyn] mbny Dwdnym yhšbw whm hiwnym bhwp hym mgbwl Bwlgr \&d Bynytyqu? Sl hym wmšm mwlykym \&d gbwl Šqšny @d hym hgdl hm hqnqriym ?ysqlby w?whrym ?mrym ky hm mbny KnSn ?k hm mtyhsym lbny Dwdnym.

„[...] also \{people of\} Morava, Karvatī \{Croatians\}, Sorbīn \{Sorbians\}, Lučanīn, Lezanīn \{*Lędjaninz, cf. $\Lambda \varepsilon v \zeta \alpha v \tilde{\eta} v o$ by Constantine Porphyrogenitus\}, Krākār \{people of Cracow\}, Boymin $\{=$ Czechs $\}$, are considered to be descendants of Dōdānim. They live on the sea shore from the borders of Bulgaria to Venice on the sea and from there to the border of the Saxons up to the big sea. Their name is Saqlabī, others say they are descendants of KenaSan, but they relate their origin to Dōdānìm."

Stanislav Segert, in Magnae Moraviae Fotes Historici, ${ }_{2}$ III: Diplomata, epistolae, textus historici varii, ed. by Dagmar Bartoňková \& Radoslav Večerka. Praha: Koniasch Latin Press 2011, 338-39; Radoslav Večerka \& Václav Blažek: Velká Morava. In: Nový encyklopedický slovník češtiny II, ed. Petr Karlík, Marek Nekula \& Jana Pleskalová. Praha: Nakladatelství Lidové noviny 2016, 1944-1946.

\section{Document confirming the union of the Prague and Moravian episcopates by Heinrich IV (1086), included in Chronica Boemorum 2.37 by Cosmas Pragensis}

Termini autem eius occidentem versus hii sunt: Tugost, que tendit ad medium fluminis Chub, Zelza (var. Zedlica) et Liusena et Dasena (var. Dacane), Lutomerici, Lemuzi usque ad mediam silvam, que Boemia limitatur. Deinde ad aquilonalem hii sunt termini: Psovane, Ghrovati et altera Chrovati, Slasane, Trebowane, Boborane, Dedosane usque ad mediam silvam, qua Milcianorum occurunt termini. Inde ad orientem hos fluvios habet terminos: Bug scilicet et Ztir cum Cracoua civitate provinciaque, cui Wag, nomen est cum omnibus regionibus ad praedictam urbem pertinentibus, quae Cracova est. Inde Ungarorum limitibus additis usque ad montes, quibus nomen est Tritri, dilatata procedit. Deinde in ea parte, que meridiem respicit, addita regione Moravia usque ad fluvium, cui nomen est Wag, et ad mediam silvam, cui nomen est More, et eiusdem montis eadem parrochia tendit, qua Bawaria limitatur. 
https://www.dmgh.de/mgh_ss_rer_germ_n_s_2/index.htm\#page/138/mode/1upDie Chronik der Böhmen des Cosmas von Prag, unter Mitarbeit von W. Weinberger herausgegeben von Bertold Bretholz. Berlin: Weidmann 1923 (Monumenta Germaniae Historica scriptores Rerum Germanicarum, Nova series: Tomus II)

„The borders in the west are: Tugost with the country extended to the boundary between the rivers of Chub and Sedlica, the \{tribes\} *Ločjane \& *Děčjane, *Ljutoméritji, *Lemozi, up to the middle of the forest, which forms the boundary of Bohemia. After that to the north these borders are situated: *Psšovjane, *Xorvati and other *Xorvati, *Sblęzjane, *Trebovjane, *Bobrjane, *Dédosjane up to the middle of the forest, where are the borders of *Milbčjane. From here to the east these rivers form the borders: Bug and Styr with the town of Cracow and the region named \{according to the river\} Wag \{today Váh\}, with all countries, which belong to the above said town, which is Cracow. From here thanks to union with the Hungarian borderland the boundary is extended up to the mountains, called Tritri \{today Tatry\}. After that on the same side, which is open to the south, the same bishop's village together with connected Moravian regions are extended up to the river, called Wag, and to the middle of the forest named More, and the same mountain on the border with Bawaria".

In this perspective, the Middle Danubian Slavic homeland according to the Old Russian chronicle 'Tale of Bygone Years', i.e. the territory of Balkan Croatia and Hungaria, is perhaps understandable as a mistaken replacement of primary North Croatia by secondary South Croatia.

\title{
Note
}

In his thick and valuable monograph, Nalepa (1968, esp. 97-112) reconstructed a similar scenario on the basis of historical phonetics and witness of West European and Byzantine historians and chroniclers, only his chronological estimations are deeper. His location of the Slavic homeland to the territory of contemporary South Poland is reinterpreted in the present study as the secondary homeland of the Southeast Slavs.

\begin{abstract}
Abbreviations
Arch. archaic, Balt. Baltic, Blr. Belorussian, Bul. Bulgarian, Cr. Croatian, Cz. Czech, d./dial. dialect, E East, Kaš. Kašubian, LSo. Lower Sorbian, Lus. Lusatian, Mac. Macedonian, Plb. Polabian, Pol. Polish, Rus. Russian, S South, SC. Serbo-Croatian, Sl. Slavic, Slk. Slovak, Sln. Slovenian, Srb. Serbian, Ukr. Ukrainian, USo. Upper Sorbian, W West.
\end{abstract}

\section{Literature}

Amirova T.A., Ol’xovikov B.A. \& Roždestvenskij Ju.V., 1975. Očerki po istorii lingvistiki, Moskva.

Arumaa P., 1964, Urslavische Grammatik. Einführung in das vergleichende Studium der slavischen Sprachen, I. Band: Einleitung - Lautlehre, Heidelberg.

Bernštejn S.B., 1961, Očerk sravnitel’noj grammatiki slavjanskix jazykov, Moskva. 
Birnbaum H., 1987, Praslavjanskij jazyk - dostiženija i problemy v ego rekonstrukcii, Moskva. Blažek V., 2008, L-epentetické a problém klasifikace slovanských jazyků, In: Člověk-jazyk-text. Sborník z mezinárodni lingvistické konference konané u přiležitosti životniho jubilea prof. PhDr. Jana Kořenského, DrSc. (České Budějovice 18.-22. záŕí 2007), ed. A. Jaklová, České Budějovice, p. 299-306.

Blažek V., 2016a, Genealogie češtiny, In: Nový encyklopedický slovník češtiny I, ed. P. Karlík, M. Nekula \& J. Pleskalová, Praha, p. 571-577.

Blažek V., 2016b, Klasifikace slovanských jazyků, In: Nový encyklopedický slovník češtiny I, ed. P. Karlík, M. Nekula \& J. Pleskalová, Praha, p. 797-806.

Chelimskij E.A., 1988, Vengerskij jazyk kak istočnik dlja praslavjanskoj rekonstrukcii i rekonstrukcii slavjanskogo jazyka Pannonii, In: Slavjanskoje jazykoznanije: X Meždunarodnyj sjezd slavistov, ed. N.I. Tolstoj, Moskva, p. 347-368.

Čejka M. \& Lamprecht A., 1963, K otázce vzniku a diferenciace slovanských jazyků, "SPFFBU" 11, p. 1-20.

Čejka M., 1972, Lexicostatistic dating and Slavonic languages, "SPFFBU” A 20, p. 39-52.

Čelakovský F.L., 1853, Čtení o srovnavací mluvnici slovanské na universitě pražské, Praha: České museum - František Řivnáč distributor). Novočeská bibliotéka, č. 17; Spisů musejních č. 47.

Dobrovský J., 1792/1818, Geschichte der Böhmische Sprache und Literatur, Prag.

Dobrovský J., 1796, Litterarische Nachrichten von einer auf Veranlassung der böhm. Gesellschaft der Wissenschaften im Jahre 1792 unternommenen Reise nach Schweden und Ruszland. Nebst einer Vergleichung der Russischen und Böhmischen Sprache, Prag.

Dobrovský J., 1809/19, Ausführliches Lehrgebäude der böhmischen Sprache1/2, Prag.

ESČ - Encyklopedický slovník češtiny, ed. P. Karlík, M. Nekula \& J. Pleskalová, Praha 2002.

Fodor I., 1961, The Validity of Glottochronology on the Basis of the Slavonic Languages, "Studia Slavica Academiae Scientiarum Hungaricae" 7/4, p. 295-346.

Hincha G., 1962, Die Glottochronologische Methode, angewendet auf slavischen Sprachen, In: II. Fachtagung für indogermanischen und allgemeine Sprachwissenschaft (Innsbruck, Okt. 1961), ed. J. Knobloch, Innsbruck, p. 117-118.

Holub J. \& Kopečný F., 1952, Etymologický slovnik jazyka českého, Praha.

Horálek K., 1955, Úvod do studia slovanských jazyků, Praha.

Ivanov V., 1990, Genealogičeskaja klassifikacija jazykov, In: Lingvističeskij énciklopedičeskij slovaŕ, ed. V.N. Jarceva, Moskva, p. 93-98.

Jagić V., 1898, Einige Streitfragen: 2. Verwandtschaftsverhältnisse innerhalb der slavischen Sprachen, "Archiv für slavische Philologie" 20, p. 13-48.

Jagić V.I., 1910, Istorija slavjanskoj filologii, St.-Petersburg.

Jakubinskij L.P., 1953, Istorija drevnerusskogo jazyka, Moskva.

Karpluk M., 1964, Relikty prasłowiańskiego 1 epentetycznego w staropolskich nazwach miejscowych, "Onomastica" 9, p. 29-63.

Kopečný F., 1949, K otázce klasifikace slovanských jazyků, “Slavia” 19, p. 1-12.

Kopitar J. (Bartholomäus), 1836, Glagolita Clozianus, Vindobonae.

Križanić J., 1666, Gramatično iskazanje ob ruskom jeziku, Tobolsk.

Kucharski A., 1833, Neue Einteilung der slavischen Sprachen, "Blätter für literarischen Unterhaltung" 1833, p. 851-852.

Lamprecht A., 1987, Praslovanština, Brno.

Lemeškin I., 2008, August Schleicher und Praha, In: Das lituanistische Erbe August Schleichers, Band I, ed. I. Lemeškin, R. Eckert, A. Sabaliauskas \& J. Zabarskaitè, Vilnius, p. 103-149.

Leskien A., 1876, Die Declination im Slavisch-Litauischen und Germanischen, Leipzig. 
Mańczak W., 1992, De la préhistoire des peuples indo-européens, “Zeszyty Naukowe Uniwersytetu Jagiellońskiego" MXLVIII, "Prace Językoznawcze" 110.

Mareš F.V., 1956, Vznik slovanského fonologického systému a jeho vývoj do konce obdobi slovanské jazykové jednoty, "Slavia” 25, p. 443-495.

Mareš F.V, 1969, Diachronische Phonologie des Ur- und Frühslavischen, München.

Mareš F.V., 1980, Die Tetrachotomie und doppelte Dichotomie der slavischen Sprachen, "Wiener slavistisches Jahrbuch” 26, p. 33-45.

Marvan J., 2000, Jazykové milénium. Slovanská kontrakce a její český zdroj, Praha.

Nalepa J., 1968, Stowiańszczyna pótnocno-zachodnia. Podstawy jedności i jej rozpad, Poznań.

Niederle L., 1953, Rukovět' slovanských starožitností, ed. J. Eisner, Praha.

Nikolajev S.L., 1994, Ranneje dialektnoje členenije $i$ vnešnije svjazi vostočnoslavjanskich dialektov, "Voprosy jazykoznanija" 3, p. 23-49.

Novotná P., 2004, Historicko-genetická klasifikace slovanských jazyků s použitím metody lexikostatistické, Brno.

Novotná P. \& Blažek V., 2005, Glottochronologie a její aplikace pro slovanské jazyky, "Sborník prací Filozofické fakulty brněnské univerzity" A 53, p. 51-81.

Novotná P. \& Blažek V., 2007, Glottochronology and its application to the Balto-Slavic languages (I), "Baltistica" 42/2, p. 185-210.

Novotná P. \& Blažek V., 2007, Glottochronology and its application to the Balto-Slavic languages (II), "Baltistica" 42/3, p. 323-346.

Novotná P. \& Blažek V., 2008, Aplikace glottochronologie při klasifikaci balto-slovanských jazyků, "Slavia" 77 (= Česká slavistika. Př́spěvky k XIV. mezinárodnímu sjezdu slavistů, Ohrid 10.-16.9. 2008), p. 125-152.

Pallas P.S., 1786-89, Linguarum totius orbis vocabularia comparativa, St. Petersburg.

Procopius, History of the wars, Books VI (continued) and VII, translated by H.B. Dewing. London-Cambridge (Massachusetts) 1962.

Schleicher A., 1850, Die Sprachen Europas in systematischer Übersicht, Bonn.

Schleicher (Šlejxer) A., 1865, Kratkij očerk doistoričeskoj žizni severo-vostočnogo otdela indogermanskix jazykov, Sankt-Peterburg: Priloženie k VIII-mu tomu Zapisok Imperatorskoj Akademii Nauk, nr. 2.

Schuster-Šewc H. [Šuster-Ševc, Ch.], 1976, Jazyk lužickich serbov i jego mesto v sem'je slavjanskich jazykov, "Voprosy jazykoznaníja" 6, p. 70-86.

Schuster-Šewc H., 2000a, Die späturslawischen Innovationen und ihre Widerspiegelung in der Isoglossenstruktur des Sorbischen (Ein Beitrag zur Dialektologie des Späturslawischen), In: Das Sorbische im slawischen Kontext. Ausgewahlte Studien, ed. J.J. Šołta, Bautzen/ Budyšín, p. 23-44.

Schuster-Šewc H., 2000b, Zu den ethnischen und linguistischen Grundlagen der westslawischen Stammesgruppe der Sorben / Serben, In: Das Sorbische im slawischen Kontext. Ausgewahlte Studien, ed. J.J. Šołta, Bautzen/Budyšín, p. 45-54.

Schuster-Šewc H., 2000c, Zur Problematik der Entstehung des Niedersorbischen, In: Das Sorbische im slawischen Kontext. Ausgewahlte Studien, ed. J.J. Šołta, Bautzen/Budyšín, p. 55-65.

Schwarz E., 1960, Sprache und Siedlung in Nordostbayern, Nürnberg.

Shevelov G.Y., 1964, A Prehistory of Slavic. The Historical Phonology of Common Slavic, Heidelberg.

Starostin S., 1989, Sravnitel'no-istoričeskoe jazykoznanie i leksikostatistika, In: Lingvističeskaja rekonstrukcija i drevnejšaja istorija Vostoka. Materialy k diskussijam na Meždunarodnoj konferencii (Moskva, 29.V.-2.VI. 1989g.), I, Moskva, p. 3-39.

Starostin S., 1999, Comparative-historical linguistics and lexicostatistics, In: Historical Linguistics \& Lexicostatistics, ed. by V. Shevoroshkin \& P. Sidwell, Melbourne, p. 3-50. 
Swadesh M., 1952, Lexico-statistic dating of prehistoric ethnic contacts, "Proceedings of American Philosophical Society" 96, p. 452-463.

Swadesh M., 1955, Towards greater accuracy in lexicostatistic dating, "International Journal of American Linguistics" 21, p. 121-137.

Šmilauer V., 1963-64, Př́ručka slovanské toponomastiky, I-II, Praha.

Tischler J., 1973, Glottochronologie und Lexikostatistik, Innsbruck: Innsbrucker Beiträge zur Sprachwissenschaft, Bd. 11.

Trubačev O.N., 2000, Iz leksičeskix kommentariev k poiskam prarodiny slavjan, In: Studia Etymologica Brunensia 1, ed. I. Janyšková \& H. Karlíková, Praha, p. 17-22.

Třeštík D., 1997, Počátky Přemyslovcu, Praha.

Vasmer M., 1941, Die Slaven in Griechenland, Berlin: Abhandlungen der Preussischen Akademie der Wissenschaften, Jg. 1941, Phil.-hist. Klasse Nr. 12.

Vepřek M., 2006, Česká redakce církevní slovanštiny z hlediska lexikální analýzy, Olomouc.

Vondrová M. \& Blažek V., 2001, Slovanské archaismy a dialektismy, In: Čeština: univerzália a specifika 3, ed. Z. Hladká \& P. Karlík, Brno, p. 311-341.

Vostokov A.Ch., 1820, Rassuždenije o slavjanskom jazyke, Rkp., first published in St. Petersburg, 1865.

Wijk N., 1924, Remarques sur le groupement des langues slaves, "Revue des Études slaves" 4, p. 5-15.

Zaliznjak A.A., 1988, Drevnenovgorodskij dialekt i problemy dialektnogo členenija pozdnego praslavjanskogo języka, In: Slavjanskoe jazykoznanija. X. Meždunarodnyj sjezd slavistov (Sofija, sentjabŕ 1988), Moskva, p. 164-177.

Žuravlev A.F., 1988, Leksikostatističeskaja ocenka genetičeskoj blizosti slavjanskich jazyov, "Voprosy jazykoznanija" 4, p. 37-51.

Žuravlev A.F., 1993, Praslavjanskij slovnik drevnenovgorodskogo dialekta s točki zrenija leksikostatistiki, "Voprosy jazykoznanija" 4, 87-98.

Žuravlev A.F., 1994, Leksiko-statističeskoje modelirovanije systemy slavjanskogo jazykovogo rodstva, Moskva.

\title{
VÁCLAV BLAŽEK
}

\section{Classification of Slavic languages: an evolution of the developmental models}

\begin{abstract}
The contribution summarizes nearly all the models of classification of the Slavic languages, presented in the past 350 years, from simple enumeration through the qualitative and quantitative approaches, typically leading to the developmental models depicted as tree-diagrams, as well as the linear and net models. The individual models, especially the quantitative ones, are discussed in detail and, finally, correlated with accounts of Byzantine historians.
\end{abstract}

Keywords: Slavic, classification, model, tree-diagram, qualitative, quantitative, comparative phonetics, lexicostatistics, glottochronology, historical correlation.

\section{Acknowledgement}

The contribution was prepared under the auspice of the Fund for Specific Research at Masaryk University, Nr. 2817. I am grateful to John Bengtson for correction of English. 